\title{
Open Skies over the Middle East ${ }^{*}$
}

\author{
Anca Cristea \\ Dept of Economics \\ $\mathrm{U}$ of Oregon
}

\author{
Russell Hillberry \\ DECTI \\ World Bank
}

\author{
Aaditya Mattoo ${ }^{\dagger}$ \\ DECTI \\ World Bank
}

April 2015

Abstract

The dynamism of air traffic markets in the Middle East obscures the persistence of restrictions on international competition. But how important are such restrictions for passenger traffic? This paper uses detailed data on worldwide passenger aviation to estimate the effect of air transport policy on international air traffic. The policy variable is a quantitative measure of the commitments under international agreements. The paper analyzes, for the first time, not only bilateral agreements, but also plurilateral agreements such as the one among Arab states. The analysis finds that more liberal policy is associated with greater passenger traffic between countries. Higher traffic levels appear to be driven by larger numbers of city pairs being served, as well as by more passengers traveling along given routes. To demonstrate the quantitative implication of the estimates, two liberalization scenarios in the Middle East are evaluated. Deepening the plurilateral agreement among Arab states would lead to a 30 percent increase in intraregional passenger traffic. Widening the agreement to include Turkey would generate significantly larger gains because current policy vis-à-vis Turkey is much more restrictive.

Keywords: air transport; air service agreements; services liberalization; plurilateral agreements

JEL: F13; L93; R48

Sector Board: Economic Policy (EPOL)

\footnotetext{
${ }^{*}$ We thank Sibel Kulaksiz for encouraging to us undertake this work. We also thank Antonia Carzaniga for generously providing us with the policy data, and Guoliang Feng for excellent research assistance. Any remaining errors are our own.

${ }^{\dagger}$ Contact: Cristea: Department of Economics, University of Oregon, 1285 University of Oregon, Eugene, OR 97405; E-mail: cristea@uoregon.edu. Russell Hillberry: Development Research Group, World Bank, 1818 H Street NW, Washington DC, 20433, United States; E-mail: rhillberry@worldbank.org. Aaditya Mattoo: Development Research Group, World Bank, 1818 H Street NW, Washington DC, 20433, United States; Email: amattoo@worldbank.org.
} 


\section{Introduction}

Turkey, long a fulcrum between the West and the East, has deepened its economic links with the European Union and is now turning to the Middle East. In this sometimes turbulent neighborhood, it is beginning to create dynamic trade links which echo past relationships albeit in a new international context. Even in the age of the internet, where geography seems passe, physical connectivity matters. Goods must be delivered, businesspersons must meet, and people must travel to forge bonds and catalyze trade. In facilitating each of these links, air transport is critical, especially in a region where terrestrial travel is fraught with difficulty. ${ }^{2}$

Turkey’s Arab neighbors are already party to the Intra-Arab Freedom of the Air Programme of the Arab Civil Aviation Commission (henceforth referred to as the “ACAC”). This Programme has in principle created conditions for more liberalized air transport, but more could be done to create fully open conditions (Schlumberger, 2010). By comparison, the bilateral air service agreements (BASAs) between Turkey and its Arab neighbors are quite restrictive. Looking ahead, policy makers must make choices: whether to deepen a plurilateral agreement like the ACAC, and whether to negotiate more liberal bilateral agreements with partners such as Turkey. We attempt to inform such decisions with quantitative estimates. In particular, we assess the benefits of a more meaningful open skies agreement in the Middle East, which would both deepen the ACAC and include Turkey as a full-fledged member. Our focus is on the Middle East but these issues have global relevance, as regions from ASEAN to Africa pursue integration of their air transport markets.

We begin by estimating a gravity model of bilateral air traffic, which helps us relate passenger flows to measures of openness in air services agreements, while controlling for other determinants of international travel. In this respect, our study builds upon prior work. Our paper contributes to a small but

\footnotetext{
${ }^{2}$ Emin Sazak, president of Turkey's contractors union, was quoted as saying, "When you want to do business in a new market...you need as direct flights as possible...” in "Companies no longer content to rely on traditional ties with west,” by Funja Guler and Daniel Dombey, Financial Times Special Report on “New Trade Routes: Turkey,” Thursday May 9, 2013.
} 
growing literature that examines the implications of liberalization in international aviation markets. ${ }^{3}$ One branch of the literature has exploited the high quality data available for air travel involving US airports, and variation in the timing of US bilateral agreements. ${ }^{4}$ This literature gives us a fairly nuanced understanding of the effects of the US agreements, including estimates of the effect of an agreement on the number of city pairs with direct flights. But the insights of this literature are related to the US market, and to the specifics of the agreements the US has signed. Another branch of the literature has used crosssectional variation in the level of policy commitments in agreements world-wide. ${ }^{5}$ This literature offers an understanding of the effects outside the US, but there is not yet evidence on particular outcomes such as growth in the number of city pairs served by direct flights.

We extend the analysis and add to the existing literature in four different ways. First, we employ a rich cross-sectional dataset on origin-destination pairs worldwide that combines the extensive country coverage observed in prior studies with the city-pair level detail that has only been exploited in studies of agreements involving the United States or, in some cases, Europe. ${ }^{6}$ This improved dataset acquired from

\footnotetext{
${ }^{3}$ Fu et al. (2010) offer a review of this and related literatures, including much earlier work on liberalizations within the United States and the European Union. Important lessons from this review about the implications of liberalization include increased hubbing and of low cost carriers for passenger growth and price competition. Dobruszkes (2009) finds that European liberalization led to service between many new city-to-city pairs, but did relatively little to increase competition within existing routes. One lesson Dobruskes draws that is perhaps applicable to other plurilateral settings is that the carriers that took most advantage of the new freedoms of the air were typically new low-cost carriers rather than existing national carriers.

${ }^{4}$ Brueckner and Whalen (2000), Brueckner (2003), Whalen (2007), and Bilotkach (2007) employ US international data on true origin-destination city-pair air traffic to investigate the price effects of inter-airline strategic alliances and market competition following the signing of OSAs. Cristea et al. (2012) and Jia and Winston (2012) consolidate the various market responses associated with the liberalization of air passenger traffic into a welfare calculation. Booz-Allen Hamilton (2007) uses time series data to link passenger growth to the timing of liberalizations between US and specific EU countries, Micco and Serebrisky (2006) find that OSAs reduce air cargo freight rates by 9 percent and increase the share of US imports arriving by air by 5 percent after 5 years or more after the agreements enter into force.

${ }^{5}$ Gonenc and Nicoletti (2001) and Doove et al. (2001) use factor analysis and information on a wide array of industry characteristics to construct aviation restrictiveness indexes. Piermartini and Rousova (2012), use information on 2300 bilateral Air Service Agreement (ASA) in force in 2005 among 184 countries to estimate the impact of air service liberalization on bilateral passenger flows. They find that increasing the degree of liberalization between two countries from the $25^{\text {th }}$ to $75^{\text {th }}$ percentile observed in the sample increases total passenger traffic by approximately 18 percent. InterVISTAS (2006) estimates a gravity model using country-pair data and specific components of the ALI index. Their estimates suggest that agreements with predetermined capacity have lower levels of passenger traffic, ceteris paribus.

${ }^{6}$ Schipper et al (2002) study liberalizations within the European Union, using the same source of data for city-tocity passenger traffic that we use. Their more limited geographic scope means that they are able to obtain richer
} 
the International Civil Aviation Organization (ICAO) allows us to expand our investigation beyond country-level gravity regressions. Second, our econometric analysis focuses not only on bilateral aviation agreements but also on plurilateral agreements. Third, we go beyond understanding the impact of aviation policy on air passenger flows and explore how liberalization affects the extensive margin of global aviation through the introduction of new direct services at the city-pair level. Finally, we use the results of our model to derive counterfactual calculations and predictions of the impact of policy changes.

The results of the paper suggest that more liberal bilateral air service agreements are associated with more passenger traffic between countries and between cities, and with more city-pairs served by direct flights. There appears to be no consistent statistically significant difference between the effects of bilateral and plurilateral agreements once we take into account the respective policy content. We use our empirical results in a counterfactual analysis in two steps. ${ }^{7}$ First, we quantify the impact of deepening the ACAC agreement by assessing how much more traffic there would be among ACAC members if the policy commitments were extended to match those of the most liberal international agreements (e.g. UKSingapore). Using country-level data we find that traffic flows would grow by approximately 30 percent. The city-pair estimates suggest that traffic along given routes would grow modestly (by 7 to 18 percent), and that there would be a significant increase in the number of city pairs served by direct international flights within the ACAC.

In the second step, we estimate the implications of Turkey’s accession to the ACAC agreement, assuming the more liberal commitments. This implies very large changes in the openness of the policy commitments, because Turkey’s existing agreements with countries in the region are quite restrictive,

data on prices, costs, and frequency of flights, and to exploit time series variation. Because our study is global, we lack comprehensive data on prices, costs and frequency, and our policy data limit us to cross-sectional analysis. ${ }^{7}$ The counterfactual analysis we conduct relies solely on parameters we estimate in the reduced form econometric models, and not on a fully specified model of the behavior of market participants. As such we only calculate first order effects of liberalization, assuming that the coefficients remain constant and that other right hand side variables do not change in response to our policy shock. We are potentially missing secondary effects that might operate, for example, through binding capacity constraints, or through spillovers to other markets. But these effects are difficult to estimate without substantially more data and a richer model structure, so we employ transparent calculations that rely on the reduced form estimates. 
when such agreements exist at all. The country level analysis of Turkey's accession to the ACAC at increased levels of policy commitments suggests that passenger traffic between Turkey and ACAC countries would more than double. ${ }^{8}$ City level analysis suggests that the increase in traffic would occur both through the growth of traffic on given routes and substantial increases in the number of city pairs served. ${ }^{9}$ In the full liberalization policy scenario that we consider, passenger growth along existing routes is modest, but the likelihood that a direct flight would occur between a given pairing of a Turkish and an ACAC city nearly triples. These large increases reflect both the significant changes in policy that we contemplate and the low probability that such city pairs are currently served by direct flights.

The remainder of the paper is organized as follows. Section II describes the two main sources of data used in our analysis. Section III chronicles trends in international air passenger travel and the restrictiveness of existing bilateral air services agreements among the countries in our sample. Section IV describes the gravity model used to estimate the links between bilateral traffic and policy while controlling for other determinants of air traffic. Section V presents the results and their main implications, while Section VI concludes.

\section{Data}

This section describes several data sets that we combine in our analysis. Our principal measure of air traffic activity is passenger travel on scheduled international flights between origin and destination cities. We seek to understand how this and related measures of air passenger traffic are associated with measures of international air policy embedded in bilateral and plurilateral air services agreements. Our data also include a number of control variables that we also describe in this section.

Passenger data. The primary data set that we use to document air passenger travel is the onflight origin and destination (OFOD) database purchased from the ICAO. The ICAO collects information

\footnotetext{
${ }^{8}$ A policy scenario in which Turkey enters at the existing level of ACAC commitments generates a rough doubling of passenger traffic between Turkey and the ACAC member states.

${ }^{9}$ An increase in the number of cities served by international travel reflects an improvement in the overall quality of air transport services because more people have the ability to take a direct flight.
} 
from national governments on international flight segments for scheduled air flights. The data we employ is the number of passengers travelling on scheduled flights for each pair of cities connected by an international flight.

This traffic measure differs from that used in Piermartini and Rousova (2012), which employs data from the International Air Travel Association (IATA) on numbers of international tickets, rather than flights. ${ }^{10}$ Ticket information follows a passenger from origin airport to destination airport, and this may contain multiple flights. Ticket information is useful for understanding customers' demand for international travel; flight information presents in detail the manner in which airlines supply segments of passengers’ international travel.

The information we study, then, is best at documenting the existence of direct flights, and the degree to which flights between specific city-pairs are used. The information we have does not contain information on prices (i.e. ticket fares), nor does it indicate class of service offered, only passenger numbers. Perhaps its most useful attribute is that it indicates whether or not a passenger travelling between two cities has to change planes, which is a key indicator of quality. ${ }^{11}$ In focusing our attention on flights, rather than tickets, we seek to complement existing evidence on the effects of air services policy on passenger travel as measured by tickets. ${ }^{12}$

The ICAO data is incomplete for years following 2010, so we use passenger data for 2010. Thus all our estimates characterize the situation in 2010. Our counterfactual analysis indicates what would have been the situation in 2010, if the policy scenarios we consider had been in place then. For example, we calculate the predicted air travel patterns if the ACAC were to adopt more liberal policy commitments.

\footnotetext{
10 The data used by Piermartini and Rousova (2012) are also aggregated at the country level, while we have information for city-to-city flights. In some cases, we also aggregate to the country level, but some suppressions in our city pair data make the city-to-city data preferable.

${ }^{11}$ Some very long flights in our database would involve a change in planes. For example, the Chicago, USA to Sydney, Australia flights in the database involve a stopover in Los Angeles, US, and a plane change. We are not able to distinguish such flights but consider the ICAO indication that there is a flight between two cities to be a close enough proxy for the existence of a direct flight.

${ }^{12}$ In their study of US data, Cristea et al (2012) find that policy does affect both flights and ticketing demand. Nonetheless they find that much of the increased passenger activity that is attributed to the air services agreement can be linked to the increased number of flights on the initial international segment.
} 
The predicted passenger routes are an estimate of what routes would have existed if the proposed policies had been in place in 2010 .

Policy data. Our primary indicator of policy is the Air Liberalization Index (ALI) score assigned to each agreement by an analysis done at the World Trade Organization (WTO). The WTO created four summary indicators of policy embodied in air services agreements. These indicators are weighted sums of individual features of the agreements: traffic rights, (lack of) restrictions on capacity, flexibility of pricing allowed, withholding restrictions such as ownership or place of business, designation, and other elements. We also examine separately the impact of these individual components of air service agreements, but because of concerns about gaps in the disaggregated data and multicollinearity between the components, our preferred specification includes only the composite ALI. We employ the standard measure of ALI produced by the WTO. Like the other measures, the standard ALI runs from 0 to 50; agreements that score 50 are the most liberal agreements. Two agreements in the database have a score of 50, the UK-Singapore agreement and the New Zealand - Brunei Darussalam agreement. One empirical difficulty is that the WTO did not provide an ALI score for the European Union, which has a common policy on international flights within the region and might be understood as a plurilateral agreement. We score the European Union at ALI = 50, but we also include a dummy variable that captures any idiosyncratic differences between the EU arrangements and bilateral arrangements that are scored at ALI $=50 . .^{13}$

The WTO index was created to score bilateral air services agreements, which are the binding agreements for most international air traffic, but more recently, a number of plurilateral arrangements have been signed. These agreements regulate air services among groups of countries, rather than just pairs of countries. While the WTO has applied to the plurilateral agreements the methodology it applied

\footnotetext{
${ }^{13}$ The dummy variable can also be understood as a control for the deep integration of transportation markets in Europe, which provides readily available alternatives to air passenger travel. With that interpretation in mind, we also included flows involving Iceland, Norway and Switzerland in our Europe Indicator dummy.
} 
to bilateral agreements, there are some difficulties with the interpretation of these scores in the plurilateral context. Notably, third-country travel arrangements are often allowed within a plurilateral agreement's membership but often not outside the membership. In order to account for possible differences in the effect of policy on traffic we also include a dummy variable indicating that the two countries' air travel is governed by a plurilateral rather than bilateral air services agreement.

Finally, we also include a variable indicating the age of the air services agreement. This should be understood primarily as a control variable. Older agreements might link countries that were especially prominent in early air travel. Agreement age might also affect policy if recent agreements tend to be more open. Whatever the dominant effect, it is useful to allow agreements to have differentiated effects based upon their age.

Control data. In order to identify the impact of policy on traffic we must also control for nonpolicy determinants of international traffic. Since our primary interest is in city-to-city traffic, we include a number of controls at the city and the city-pair levels. The primary city-specific data we include is city population. ${ }^{14}$ City-to-city distances are included as further controls; specifically, we employ great-circle distances as calculated from the geographic coordinates of each city. Logged distances are included in the regression as are squared log distances. We also include a measure of the absolute number of hours of difference in time between the two cities as such time differences might affect air travel demand.

There are several control variables at the country and country-pair levels. Country level measures of GDP per capita, population, and land area are taken from the World Development Indicators (WDI), and are included as potential determinants of the overall demand for air travel. Since our data pertains to the number of passengers traveling on direct flights between specific pairs of cities, rather than the entire origin to destination journey, we control for the attractiveness of locations that serve as hubs by including the total number of departures from each location (also from the WDI dataset). Country-pair control

\footnotetext{
${ }^{14}$ The population data are taken, in the first instance from UN Department of Economic and Social Affairs, Population Division. This data set does not report populations for some smaller cities. We supplement this data with data from the web site www.citypopulation.de, an aggregator of national population statistics. In each case the city populations are reflective of larger urban areas, not simply the city boundaries.
} 
measures include dummy variables indicating that a) one country colonied the other, b) the two countries share a common language, c) the countries share a land border, d) are both democracies, e) are both WTO members, and f) are both members of a common regional trade agreement. ${ }^{15}$ Continuous variables on country pair relationships include a) annual average temperature difference, an indicator for tourism demand; ${ }^{16}$ b) total bilateral trade, and c) the share of total trade that involves face-to-face interactions (that is, trade that falls under the “differentiated products” classification in Rauch (1999)).

\section{Descriptive Statistics}

In this section we provide a brief description of patterns of passenger travel and policy.

\section{III.1 Trends in International Air Passenger Travel}

In order to understand the context of our work on the 2010 data, we provide some initial summary statistics about the levels and changes of air passenger traffic in the years 2000 and $2010 .{ }^{17}$ Table 1 reports passenger traffic for select origin and destination countries using the on-flight origin and destination data from the ICAO. These figures report total scheduled air passenger traffic. These figures do not include traffic on non-scheduled flights, such as charter flights, but include scheduled traffic accounts for most international air passenger travel. The table also reports the number of scheduled flights.

The table shows that Turkey has seen rapid growth, both inbound and outbound, within the ACAC and with the rest-of the world. Official decisions to lift visa requirements for many Arab countries and to sign free trade agreements with Morocco, Tunisia, Libya and Jordan have increased the flow of

\footnotetext{
15 The colonial, language and common border dummy variables are taken from CEPII, and described in Head, et al (2010). The classification of governments as democracies or not is done by The Polity IV project. These data are available here: http://www.systemicpeace.org/polity/polity4.htm.

16 The underlying data for the average monthly temperature differences are an indicator for tourism demand, and are taken from the World Bank’s Climate Change Knowledge Portal: Historical Data, at http://data.worldbank.org/data-catalog/cckp_historical_data.

172010 is the most recent year for which the ICAO data is complete.
} 
people and goods between Turkey and the Middle East and North Africa. ${ }^{18}$ Growth within the ACAC has also been rapid, although varying over origins and destinations. The spectacular levels of growth in traffic involving the UAE are notable, and observed across most countries in the region. ${ }^{19}$

The figures in Table 1 are consistent with Turkey’s aspirations to become a regional hub for international air travel. Given the underlying fundamentals this seems possible, but there is not, as yet, a firm international policy setting that can facilitate such a development. We turn to an empirical model to help us understand the likely effects of policy change.

\section{III.2 Patterns of Policy Governing Air Passenger Traffic}

As noted above, most air traffic is governed by bilateral air service agreements between pairs of countries, and some by plurilateral agreements between groups of countries. We are interested primarily in two sets of agreements: one relating to traffic between the Arab countries; and the other to traffic between Turkey and each of the Arab countries.

The Arab Civil Aviation Commission (ACAC) was created in 1999 as part of an agreement to liberalize intra-Arab air services by gradually reducing restrictions for carriers of member states. ${ }^{20}$ This resulted first in the signing of 17 bilateral open skies agreements among Commission states. In December 2004, several Arab League members - Bahrain, Egypt, Iraq, Jordan, Lebanon, Oman, Palestine (West Bank and Gaza), Somalia, Sudan, Syria, Tunisia and the Republic of Yemen - signed a plurilateral agreement referred to as the Arab League Open Skies Agreement. The Agreement clearly covers the first four freedoms of the air (Annex Table 1). ${ }^{21}$ The agreement also seems to go beyond these freedoms

\footnotetext{
18 “Regional push resumes following Arab Spring,” by Borzou Daragahi, Financial Times Special Report on “New Trade Routes: Turkey,” Thursday May 9, 2013.

${ }^{19}$ Often, these growth rates are off of a relatively small base.

20 The discussion of the Arab League Open Skies Agreement draws upon Schlumberger (2010).

21 The freedoms of the air are described in ICAO (2004) as the following: 1st is the right to fly over a foreign country, without landing there; 2nd is the right to refuel or carry out maintenance in a foreign country on the way to another country; 3rd is the right to fly from one's own country to another; 4th is the right to fly from another country to one's own; 5th is the right to fly between two foreign countries during flights while the flight originates or ends in one's own country; 6th is the right to fly from a foreign country to another one while stopping in one's own country for non-technical reasons; 7th is the right to fly between two foreign countries while not offering flights to one's own
} 
because it includes traffic "to and from any of the territories of the State parties." As Schlumberger (2010, p 69) argues, “Clearly, fifth freedom rights are included, because any destination within state parties beyond the initial destination is included. The Agreement even seems to grant seventh freedom rights, as it does not specify that traffic needs to route back over the departure point in the initial state party. The only freedom that is clearly excluded is cabotage, the eighth freedom.”

The other provisions of the ACAC open skies agreements are also presented in Annex Table 1. Article 5 entitles each state party to designate one or more air transport companies to benefit from the provisions of the agreement, provided the companies have substantial ownership or effective control by one or more state parties, or their citizens and their main place of business is in one of the state parties. Article 7 provides the freedom of capacity. Article 8 allows companies to determine their tariffs on the basis of commercial considerations.

The rules governing the ACAC relationship with third parties, such as Turkey, are specified in Annex Table 2. Particularly relevant is Article 31 concerned with future bilateral agreements between members of the ACAC and third parties. It states that, “The States Parties shall not grant rights or give undertakings to third party States where such rights or undertakings could restrict or affect the rights conferred upon the States Parties under this Agreement.” And “The rights conferred upon the States Parties under this Agreement shall not be subject to individual negotiations or dealings with any third party state or states where such negotiations or dealings could affect the rights of the other State Party/States Parties.” These provisions would seem to create a presumption in favor of negotiations with ACAC as a whole rather than separately with individual member states - much as the European Commission has discouraged the negotiation of open skies agreements between EU member states and third parties like the United States. But separate negotiations are not ruled out.

Article 32 governing accession provisions for third parties is, therefore, also relevant. It states that "The State Party/States Parties shall have the right to exchange the air transport rights stipulated in

country; 8th is the right to fly between two or more airports in a foreign country while continuing service to one's own country; 9th is the right to fly inside a foreign country without continuing service to one's own country. 
this agreement on a basis of reciprocity with any alliance of third party states grouped in a regional or sub-regional economic integration organization. To this end, the States Parties may call on the assistance of the Arab Civil Aviation Commission or any other negotiating body which may be entrusted with this task."

WTO (2007) has assigned a fairly liberal score of 39 to the ACAC and we apply this to each of the bilateral relations between ACAC members. Recall that 50 represents the most liberal score so this is a fairly liberal agreement. The bilateral agreements between Turkey and ACAC members (where they exist, Annex Table 3) have been assessed by the WTO to be comparatively restrictive. The agreements between Turkey with Jordan, Lebanon and Syria each have scores of 11; the agreements with Iraq and Tunisia have scores of 10; and the agreement with Egypt has a score of only 4. Interestingly, direct air transportation services with several key countries are not covered by bilateral air services agreements as recorded by ICAO in 2005. These include the United Arab Emirates, Saudi Arabia, Algeria, Libya, Bahrain, Kuwait, Qatar and Yemen. We, therefore, do not have any information on the restrictiveness of these bilateral agreements. Nevertheless, the large gap between the liberal scores assigned to the plurilateral agreement governing intra-ACAC traffic, and the relatively restrictive scores assigned to bilateral agreements governing Turkey's traffic with individual ACAC member states suggests that liberalization of Turkey's relations with the ACAC could have a significant impact on traffic.

\section{Estimation Procedure}

This section describes the estimation strategy that we pursue in order to understand the effects of air services liberalization on international air passenger transport. We focus our analysis on two important margins of expansion of the aviation industry: 1) the intensive margin, defined as the volume of passengers within a geographic market, and 2) the extensive margin, defined as the number of distinct markets where international direct air service is provided. We consider an aviation market as an origindestination pair, and conduct our analysis at two levels of data aggregation: country-pair as well as citypair levels. While the specification of the regression model differs minimally across outcomes of interest 
and bilateral market definitions, each data exercise sheds light on a different aspect of the international aviation market.

We think of international air passenger flows between origin and destination locations as analogous to bilateral international trade flows, and rely on the gravity model of trade for the empirical analysis. ${ }^{22}$ Our baseline empirical specification can be written as follows:

$$
\begin{gathered}
\log \text { Pax }_{i j}=\beta_{0}+\beta_{1} \text { ALI }_{i j}+\beta_{2} \text { ASAPluri }_{i j}+\beta_{3} \log \text { ASAage }_{i j}+ \\
+\beta_{4} \log \text { Dist }_{i j}+\beta_{5} \log \text { Dist }_{i j}^{2}+\beta_{6} \operatorname{logPop}_{\mathrm{i}}+\beta_{7} \operatorname{logPcGDP}_{\mathrm{i}}+\beta_{8} \log \text { Pop }_{\mathrm{j}}+\beta_{9} \operatorname{logPcGDP}_{\mathrm{j}}+ \\
+\beta_{10} \text { Border }_{\mathrm{ij}}+\beta_{11} \text { Colony }_{\mathrm{ij}}+\beta_{12} \text { Lang }_{\mathrm{ij}}+\beta_{13} \operatorname{logTrade}_{\mathrm{ij}}+\gamma \mathrm{X}_{\mathrm{i}}+\delta \mathrm{X}_{\mathrm{j}}+\theta \mathrm{Z}_{\mathrm{ij}}+\varepsilon_{\mathrm{ij}}
\end{gathered}
$$

where $\log$ denotes the natural logarithm; $i$ and $j$ index the origin, respectively the destination locations (i.e., countries or cities); $X_{i}, X_{j}$ and $Z_{i j}$ represent vectors of additional control variables that are specific to origin $i$, to destination $j$, or to the bilateral pair $i j .{ }^{23}$ The dependent variable Pax denotes the number of passengers traveling from $i$ to $j$ during the year 2010. The aviation liberalization index $A L I$, characterizing the bilateral pair $i j$, is our variable of interest. We expect that more liberal agreements between two countries will generate larger international passenger flows, $\beta_{1}>0$.

We also include a dummy variable indicating whether the agreement governing air traffic on the ij route is a plurilateral. The $\beta_{2}$ coefficient associated with the plurilateral dummy is included to measure any average tendency for plurilateral agreements to differ from bilateral agreements in their effects on air

\footnotetext{
${ }^{22}$ The gravity equation is considered the workhorse model of international trade because of its empirical success in explaining the volume of bilateral trade between two trading partners. It was pioneered by Tinbergen (1962), and later on Anderson (1979), Bergstrand (1985), Anderson and van Wincoop (2003), and others have contributed with theoretical microeconomic foundations of the gravity equation. Over time, the gravity equation has been successfully applied to analyze many other bilateral relationships such as foreign direct investments (Brainard, 1997), financial flows (Portes and Rey, 2005), migration (Karemera et al., 2000) or international travel flows (Neiman and Swagel, 2009).

${ }^{23}$ We do not specify this equation using origin and destination specific fixed effects, as is often done in gravity models of international trade. The primary reason for this is that many of the countries in our country sample, along with the vast majority of the cities in our city sample, have a relatively small number of partner countries/cities. The large number of zero observations that flow from that fact implies that the binary choice model we estimate is a critically important feature of the analysis, and large numbers of fixed effects are not appropriate for binary choice models, especially when the right hand side variable is dominated by zeroes.
} 
passenger traffic. This estimate is conditional on the policy measures included in the agreement, as measured by the $A L I$ score. International policies require a phase-in period for the full benefits of the new policy to be reflected on the market outcomes. ${ }^{24}$ We thus include as control variable in the regression model the age of the air service agreement signed between countries $i$ and $j$, and expect it to have a positive effect on air traffic. ${ }^{25}$

Apart from the bilateral ALI between country pairs, we also include as control variables in an extended specification an origin-specific average ALI score and a destination-specific average ALI score with respect to third countries. Generally, in estimating a gravity model it is essential to analyze not just bilateral trade resistance, measured by the barriers to trade between a pair of countries, but also multilateral trade resistance, measured by the barriers to trade that each country faces with all its trading partners. More specifically, the inclusion of the measures of average ALI with respect to third countries is important because, as described above, our data captures the number of passengers traveling on direct flights between pairs of cities and does not capture the entire origin to destination journey, which may contain multiple flights. Thus, the attractiveness of flying a particular bilateral route also depends on the openness of the country or city pair vis-à-vis other destinations. ${ }^{26}$

Another set of control variables are those motivated by the gravity model. We use distance and distance squared as proxies for route-specific operation costs, which affect airfare and thus the demand for travel. We allow distance to affect traffic non-linearly in order to control for elements such as the fixed cost of takeoff and landing. Population (Pop) and per-capita income (PcGDP), measured at origin

\footnotetext{
${ }^{24}$ Micco and Serebrisky (2004) and Cristea et al. (2012) provide evidence for the US that the effect of Open Skies Agreements is fully reflected in price and quantity outcomes for freight transport services and air passenger travel 3 to 5 years after they enter into effect.

${ }^{25}$ As noted above, the age of the agreement might also affect traffic numbers because older agreements linked countries with stronger political and economic links, or because older agreements tend to be less liberal.

${ }^{26}$ We use the same average ALI measures in both the country-level and the city-level regressions. The reason is that ALI measures are only available at the country-level. If we were to construct city-level measures based on actual routes served by specific cities, we risk creating an endogenous variable.
} 
and at destination, account for the level of aggregate demand. ${ }^{27}$ All else equal, large populations and high income levels are expected to have a significant positive effect on air passenger traffic.

Dummy variables that indicate the presence of a border, common colony and common language are included to capture proximity, socio-cultural and historical links between the origin and destination locations. All else equal, neighboring countries rely more on ground than on air transport, implying an expected negative effect of a shared international border on the volume of air passenger traffic. On the other hand, sharing a common language and colonial ties increases the similarity between the cultures, norms and institutions of the two locations, inducing more leisure and business travel. Bilateral trade between origin and destination countries is also included because more trade may require more business travel. $^{28}$

Other control variables considered in the estimation and summarized by the three variable vectors are: the geographic area of countries (to account for population density and growth of extensive margin expansion), membership in free trade agreements and in the World Trade Organization (aviation liberalization may reflect broader trade liberalization efforts), differences in average annual temperatures (a proxy for leisure travel and tourism), differences in time zones (which increase the non-monetary cost of travel and doing business), and the trade share of differentiated goods (which may be especially likely to require face-to-face meetings for contract negotiations and quality inspections). We include a dummy for whether both countries are democracies in year 2005 (they are more likely to consider signing a liberal agreement, but also more likely to take advantage of the benefits the ASA offers). We include a dummy variable for country pairs inside Europe to correct any bias that might emerge because the EU arrangements were not scored by the WTO and we have simply applied a score of 50 on these routes.

\footnotetext{
${ }^{27}$ Even though air traffic flows reflect only one direction of travel, the destination-specific variables influence the level of demand at the origin through economies of density effects and reduced round-trip operation costs.

${ }^{28}$ The baseline regression includes bilateral trade since we think it is an especially important control that is a good proxy for economic links, and because higher levels of trade may increase demand for passenger travel. Being sensitive to the concern that trade is possibly endogenous to passenger traffic, we have also estimated the models without including bilateral trade and find that the coefficients are quite stable. We report results for the specification in (1) and (3) but the other results are available on request.
} 
Finally, as noted above, since our data pertains to the number of passengers traveling on direct flights between specific pairs of cities, rather than the entire origin to destination journey, we also control for the attractiveness of cities that serve as hubs within the global aviation network. For example, we may observe large numbers of passengers traveling between Alexandria and Doha simply because Doha is a hub for Qatar Airways and offers a range of connection to and from other cities. In the country level regressions, we therefore include the total number of departures operated from each country within a pair. The more departures a country offers, all else equal, the more likely it is that passengers use airports in that country as connecting points for travel beyond that country. Since the departure data is only available at the country level, in the city level regressions we assume that the distribution of worldwide departures across cities within a country is proportional to the share of routes offered by each city of the country to any destination in the world.

We first estimate the regression equation (1) using country-pair aggregate data on air passenger traffic flows. This exercise informs our understanding of the relationship between policy and air passenger traffic between countries. We estimate country-level regression specifications using ordinary least squares (OLS) methods.

This specification raises three estimation issues: reverse causality, omitted variables and zero passenger flows, respectively. The primary concern of these three is that country pairs characterized by large air traffic flows are more likely to cooperate and negotiate a liberal ASA. It is also possible that country pairs with little or no direct air services connecting them sign liberal ASAs in order to encourage air traffic growth. In any case, endogeneity is mitigated by the fact that most of the agreements in our sample were signed long before the period we examine and therefore could reasonably be treated as exogenous to recent traffic flows. ${ }^{29}$

\footnotetext{
${ }^{29}$ The mean and median age of an air service agreement in our sample is 18 years. Only 11 percent of the agreements observed in our sample have entered into effect within five years prior to 2010. Among the oldest agreements are the ones involving European countries, some of which go as far back as 55 or 60 years.
} 
The second concern is that there are other bilateral factors that lead both to higher traffic flows and to more liberal agreements. We attempt to address this concern by including in our specification an unusually wide range of bilateral covariates. These include bilateral trade flows, the share of differentiated products in trade, joint membership in the WTO, and more. The inclusion of these variables mitigates concerns that our results are sensitive to omitted variables bias, even though some of these variables too are potentially endogenous. Fortunately, our coefficients are not sensitive to the inclusion of these additional controls in the sample.

Finally, one last estimation issue is the existence of zero traffic flows in our dataset. Because our dependent variable is in log format, we lose from our estimation sample all the origin-destination pairs with zero air service activity. Even when positive, the passenger number information on certain city-pairs operated by a single airline is suppressed by ICAO for confidentiality. This further complicates the estimation strategy. And since the data censoring is not based on the actual number of passengers, standard estimation procedures such as Tobit regressions (which correct for bottom coding) do not apply in this case. The econometric problem of zero dependent variables is pervasive in this literature on the gravity equation, and authors are often constrained to estimate regression models conditional on positive bilateral flows. Nevertheless, we do attempt to take a step further and account for zeros by estimating equation (1) using the Poisson method (Santos Silva and Tenreyro, 2006).

\section{Estimation using city-pair data}

The growth in country-level bilateral air passenger traffic generated by air services liberalization can be explained by growth along the extensive margin (i.e., the number of direct city-pair aviation services), and along the intensive margin (i.e., growth in traffic within a city-pair). We take advantage of the level of disaggregation in the ICAO dataset to estimate a regression model similar to equation (1) using city-pair air traffic data. This exercise corresponds to an analysis of air services liberalization along the intensive margin. We modify the regression in equation (1) slightly in order to reflect city specific characteristics. First, we replace the country level bilateral distance terms with city-pair distances. 
Second, we add information on city population levels at origin and destination. ${ }^{30}$ Last, as noted above, we construct a city-specific variable to capture the "hub-ness" of a city by measuring the fraction of all the international departures from a given country that originate in that city. All else equal, consumers attach great value to the flight options of a hub city, while airlines can economize greatly on the fixed cost of ground operations when serving passengers out of the same city. Thus, we expect city "hub-ness" measured at origin and destination to enter positively in the regression.

One advantage of the city-pair data sample is that it allows us to investigate how air services liberalization influences market entry, and thus the probability that a given city-pair becomes connected through a direct flight service. We exploit the patterns of ones and zeros for the existence of a direct flight service within a city-pair to estimate a logit regression model. ${ }^{31}$ Therefore, we define:

$$
\text { AirService }_{i j}= \begin{cases}1 & \text { with probability }=p \\ 0 & \text { with probablity }=1-p\end{cases}
$$

and estimate the following logit regression model:

$$
\begin{gathered}
\log \left(\frac{\mathrm{p}_{\mathrm{ij}}}{1-\mathrm{p}_{\mathrm{ij}}}\right)=\gamma_{0}+\gamma_{1} \text { ALI }_{\mathrm{ij}}+\gamma_{2} \text { ASAPluri }_{\mathrm{ij}}+\gamma_{3} \log \text { ASAage }_{\mathrm{ij}}+\gamma_{4} \operatorname{logDist}_{\mathrm{ij}} \\
+\gamma_{5} \operatorname{logDist}_{\mathrm{ij}}^{2}+\gamma_{6} \operatorname{logPop}_{\mathrm{i}}+\gamma_{7} \operatorname{logPcGDP} \mathrm{i}+\gamma_{8} \operatorname{logPop}_{\mathrm{j}}+\gamma_{9} \operatorname{logPcGDP}_{\mathrm{j}} \\
+\gamma_{10} \text { Border }_{\mathrm{ij}}+\gamma_{11} \text { Colony }_{\mathrm{ij}}+\gamma_{12} \text { Lang }_{\mathrm{ij}}+\gamma_{13} \operatorname{logTrade}_{\mathrm{ij}}+\phi \mathrm{X}_{\mathrm{i}}+\delta \mathrm{X}_{\mathrm{j}}+\theta \mathrm{Z}_{\mathrm{ij}}+\mathrm{v}_{\mathrm{ij}}
\end{gathered}
$$

The set of explanatory variables are the same as in the previous regressions. Given the form of the dependent variable, the estimated coefficients will be interpreted as an effect on the odds of a direct flight service connecting cities $i$ and $j$. As an example, based on the model in equation (3), a one unit increase in the bilateral $A L I$ leads to a change in the odds of a direct flight equal to $\exp (\gamma)$.

\footnotetext{
${ }^{30}$ We keep in the city-pair regression specifications the population variables in order to capture some information on the spatial distribution of population within each country. For example, if a significant fraction of a country's population lives outside a gateway airport, the city size variable is not going to be sufficient in order to predict the size of city-pair passenger flows.

${ }^{31}$ Out of the various ways to model binary response variables, we choose a logit regression model because of its estimation performance when there is a very large number of zeros in the sample.
} 


\section{Results and Implications}

\section{V.1 Country Level Estimates}

We start by estimating equation (1) using ordinary least squares and bilateral country-level data on the volume of on-flight air passenger traffic. The results are reported in Table 2. Column 1 considers a parsimonious specification with the ALI variable entering on its own. The coefficient of interest suggests that air services liberalization has a positive and significant effect on bilateral air traffic. A 1-unit increase in ALI leads to a 1.8 percent increase in air passengers.

All the control variables considered in the baseline model enter the regression with the expected sign and are generally highly significant. Larger distances between the two countries increase the demand for air traffic reflecting fewer alternative modes of transport. However the effect is increasing at a decreasing rate, with too large distances discouraging air travel because of the increasing travel costs. The economic size of each of the two countries, captured by their GDP levels, has a positive effect on air passenger travel, as does the volume of bilateral trade. Having a common official language and common colonial ties also affects positively air travel between countries. This indicates that cultural, social and institutional similarities reduce travel costs, encouraging the cross-border mobility of people. The regression results suggest that a country’s land area reduces international travel, conditional on population and income. This result is consistent with the fact that population density matters for the efficiency of an aviation network.

The specification in column 1 assumes that plurilateral and bilateral agreements have the same effects on passenger travel. In column 2 we include a dummy variable that indicates whether traffic along a route is governed by a plurilateral agreement. This coefficient is not statistically significant, and the ALI coefficient in this specification increases slightly, to 0.021 , but is largely unaffected.

One concern with the estimates obtained so far is the possibility of endogeneity associated with the signing of liberal aviation agreements. One source of endogeneity is the omission of variables that are correlated with both the level of air traffic and the extent of aviation liberalization. When omitted from 
the model, the effect of these variables can load onto the coefficients of interest. To mitigate this issue, in column 3 we extend the regression model to account for additional control variables. In particular, we consider two measures of trade policy integration: membership in regional trade agreements (RTA) and in the WTO. They may predict the likelihood of services liberalization, and also influence the volume of air passenger flows. We also consider the share of trade in differentiated goods, following Rauch (1999), as it has been shown that face-to-face communication is very important when trading such goods (Cristea, 2011). Furthermore, we include a dummy variable indicating that the origin and destination countries are both democracies, as democracy may affect both the mobility of people and the countries' intentions to liberalize aviation markets. We account for differences in average annual temperatures and in time zones between the countries, as they also influence the volume of travel and, through that, countries' incentives to liberalize their aviation markets.

In column 3 we also take into account the network aspects of air transport, and the fact that our data does not capture passenger's entire itinerary, by including measures of openness vis-a-vis third countries and the "hub-ness" of particular locations, as discussed above. We find that the average ALI at origin and destination enters with a significant negative sign. One interpretation, consistent with the notion of multilateral resistance, is that the higher ALI is towards third destinations, the more options a passenger has, and so the likelihood of traveling on any particular route is lower, ceteris paribus. We find that the total world departures for origin and destination countries enter with a positive and significant sign, confirming our intuition that "hub-ness" has a positive impact on traffic. Again, the inclusion of these variables does not affect the coefficient for ALI.

Column 4 offers a robustness check on the log-linear specification. The results in column 4 are based on estimation of a Poisson model. We estimate the model only over the observations with positive reported passenger flows. The large number of zero observations in our data offers one reason for doing so. Another reason is that some country pairs have zero recorded traffic due to data suppression. Again, qualitatively, the Poisson specification preserves the data patterns identified in the prior specifications. 
The final row of Table 2 reports the estimates of a simple counterfactual exercise in which we calculate the quantitative impacts of policy changes on passenger traffic that are implied by the model. Specifically we consider changes in the ACAC commitments that would raise the ALI score from its current level (39) to that of the most liberal of the bilateral agreements (50). These estimates imply outcomes that would have occurred if more liberal policy had been in place in 2010. Our estimates suggest that traffic between pairs of ACAC countries would have been 22 to 39 percent higher, depending on the specification. These are our best estimates of the likely impact of a significant liberalization of commitments within the existing ACAC membership.

To summarize, the results from the aggregate gravity model reported in Table 2 indicate that aviation liberalization has a direct and positive effect on air traffic. The estimated response of passengers to the ALI policy index is stable across several specifications. There does not seem to be sufficient evidence to conclude that, conditional on their policy provisions, the plurilateral and bilateral agreements differ substantially in their effect on passenger flows. The estimated effects of policy on passenger travel imply that implementation of policies consistent with the most liberal bilateral agreements would imply an increase in passenger travel of roughly 30 percent.

\section{V.2 City Level Estimates}

The available cross-country evidence on the effects of air services agreements on air passenger traffic relies on measures of traffic between countries, as in Table 2. Studies of the US open skies agreements exploit data documenting flights between US and international cities. Cristea et al (2012), for example, show that the US agreements led to a shift of traffic away from primary hubs, so that passengers now enjoy many more direct international flights. In this section we estimate the impacts of policy on city level flows, in two ways. Initially, we estimate a model of traffic along existing city-to-city routes. Next we turn to a model that predicts the existence of an international flight between two cities. 
Table 3 reports the results from estimating the regression model in equation (1) at a city pair level, using only data on origin-destination aviation markets with positive air traffic flows. ${ }^{32}$ This corresponds to an analysis of the intensive margin response to aviation liberalization. The specifications in Table 3 follow the same sequence as in Table 2. The coefficient of the ALI variable is positive and significant in all the specifications. These results suggest that the increase in bilateral traffic between countries associated with a more liberal air service agreement is based in part on an expansion of traffic along the intensive margin, i.e. more passengers travel along existing routes.

The coefficients on other control variables are generally similar to those in the country-level specification and accord with intuition. Interestingly, while the population of origin and destination countries is not a significant determinant of country-level traffic after controlling for other factors such as physical and economic size, the population of both origin and destination cities does matter for city-level traffic. This difference could be because of the absence of city-level controls for physical and economic size. Also, plurilateral agreements have a negative and significant coefficient in one of the three specifications in which they appear. The fact that the coefficient is not stable across specifications in either sign or statistical significance militates against any strong interpretations or policy implications. However, part of the explanation may lie in the partial implementation of certain plurilateral agreements that are very liberal on paper. ${ }^{33}$ As in Table 2, the final row of Table 3 reports counterfactual estimates consistent with a full liberalization of policy within the ACAC, conditional on the ALI coefficient in each column. The estimated increase in passenger traffic among pairs of ACAC cities with existing flights is estimated to be between 7 and 18 percent. The existence of economically and statistically significant effects of policy in city-level regressions that are smaller than the effects in the country-level regressions

\footnotetext{
${ }^{32}$ We estimate the selection equation (i.e. whether there is a flight) separately from the level equation (how much traffic is on the flight), without using the selection equation results to inform the level equation, as in the Heckman procedure for example. Such procedures are extremely sensitive to misspecification when there are a large number of zero observations, as there are in our data.

${ }^{33}$ For example, the average ALI for bilateral ASA in our sample is 11, while the average ALI for plurilateral air service agreements is 42 . The latter value is determined by intra-EU and US-EU agreements, which is liberal in both principle and practice, but also by the ACAC and Yamoussoukro agreements, which are also liberal in principle but it is hard to determine whether they are also liberal in practice.
} 
suggest an important role for the extensive margin, that more liberal policies allow for more direct flights between city pairs. This would be consistent with city-level research on the US agreements. ${ }^{34}$

Table 4 reports the results from estimating the logit model described by equation (3). It is useful to emphasize the large difference between the number of city-pairs with positive air traffic reported by ICAO, and the number of city-pairs used in the logit model, where the great majority of the pairs formed among cities in the sample have no air service activity. Looking across the specifications reported in Table 4, the first thing to point out is that the pattern of estimates matches the findings from the country and city level models: air services liberalization increases the odds of a direct flight between any two cities belonging to the signatory countries, and any implied differences between plurilateral and bilateral agreements are not consistently statistically significant. The scale of the policy coefficient depends on the exact specification. But the final row of Table 4 illustrates that the quantitative implications are not so different. That row shows that raising ALI to 50 among ACAC cities would increase the odds of a flight between any two given cities by a factor of 1.2 to 1.4 .

\section{V.3 Impact of Specific Provisions of Air Service Agreements}

So far we have relied on the ALI score as a single, comprehensive indicator of market openness. However, a difference in ALI values may arise from differences in any of the constituent elements of air service agreements, such as restrictions on freedoms of the air, capacity or frequency, pricing or ownership. The impact of a change in ALI values on our variables of interest may differ depending on which underlying provision is driving the change. ${ }^{35}$ Even though the gaps in the data on constituent provisions and the issue of multicollinearity between the provisions preclude a full-fledged examination of their differing significance, it is possible to carry out a preliminary exploration.

\footnotetext{
${ }^{34}$ See Cristea, et al (2012).

35 The counter-factual simulations in this paper, discussed below, are largely free from this problem. When ALI reaches 50, the markets are almost fully liberalized with few restrictions on capacity, frequency, pricing, etc.
} 
The left hand panel of Table 5 (columns 1-6) reports the results obtained by estimating the regression model given by equation (1) on air traffic data at country level. The right hand panel of Table 5 (columns 7-12) reports the results obtained by estimating the regression model given by equation (3) using city level data on whether a given city-pair is connected by a direct flight. ${ }^{36}$ In each case, we first examine specific categories of provisions (freedoms of the air, capacity, pricing, etc.) separately and then bring them all together in a comprehensive regression (in columns 7 and 12). Within each category of provisions, we include dummies to reflect the existence of relatively liberal provisions and omit the dummy to reflect the absence of such provisions. For example, in the category pricing, we include the three relatively liberal provisions, free pricing, dual disapproval and country of origin disapproval, and omit the most restrictive provision, dual approval. Therefore, we expect the included dummies to have positive coefficients.

The results are broadly consistent with intuition though the differences between country and citylevel regressions are not easy to explain. The 5th Freedom is about the right to fly between two foreign countries on a flight originating or ending in one's own country. We would expect that the freedom to combine a segment $\mathrm{AB}$ with another segment $\mathrm{CA}$ or $\mathrm{BC}$ makes the segment $\mathrm{AB}$ more attractive, as turns out to be the case in the country-level regressions (columns 1 and 6). The limited number of observations obliged us to bundle together the $7^{\text {th }}$ Freedom, which is about the right to fly between two foreign countries while not offering flights to one's own country, and cabotage, which is usually about the 8th Freedom, i.e. the right to fly between two cities inside a foreign country, while coming from or continuing to one's own country (pure cabotage is the relatively rare 9th Freedom). This bundle of freedoms has a positive and significant effect on the likelihood of a city pair being served (columns 7 and 12).

On capacity, the most liberal Free Determination (which leaves capacity determination out of regulatory control) is positive and significant at the country-level when only capacity categories are

\footnotetext{
${ }^{36}$ All specifications include the full set of control variables and fixed effects used in previous specifications, but for space considerations they are omitted from the table. Also, all the estimations account for individual ASA components that are missing or that are codified as "other". These are also omitted from the table due to space constraints.
} 
entered (column 2), while Bermuda 1 (which gives a limited right to the airlines to set their capacities without a prior governmental approval) is positive and significant at the city level even when all categories are entered (columns 8 and 12) (the restrictive Predetermination has been dropped). On pricing, the relatively liberal Dual Disapproval (in which both countries have to disapprove tariffs in order to make them ineffective) is positive and significant across all specifications (columns 3, 6, 9 and 12) (compared to the omitted restrictive Dual Approval in which both parties have to approve the tariff before it can be applied). Multiple designation (which allows the right to designate more than one airline to operate a service between two countries) is also positive and significant across all specifications (columns 5, 6, 11 and 12) (compared to the omitted Single Designation). Some of the other variables are not consistently significant across all specifications and in three instances (origin country pricing and cooperative arrangements) they also do not have the expected positive sign.

Nevertheless, these preliminary results based on the individual provisions of air service agreements broadly support the results obtained with the composite ALI. A closer look at the impact of these individual provisions on the extensive and intensive margins at both the country and city level is an important area for future research.

\section{V.4 Simulating a Turkey-ACAC agreement}

The policy experiment we have in mind when designing the counterfactual exercises is the inclusion of Turkey in regional air services arrangements equivalent to those of the ACAC. Air passenger markets in the Middle East are changing rapidly. Turkey, which aspires to serve the region as a hub, has seen rapid growth in air passenger traffic, within the region and with the rest of the world. The policy environment, however, has not kept pace with these developments. Turkey is not a member of the ACAC. Instead, WTO measures suggest that Turkey’s bilateral passenger traffic arrangements with these countries are quite restrictive. We consider a scenario in which the ACAC and Turkey negotiate an agreement at the most liberal level of policy commitment available, ALI $=50$. Because existing policy 
commitments are quite restrictive in most cases, this represents a dramatic change in the degree of air services liberalization between Turkey and the ACAC member states.

Table 6 reports a number of useful statistics along with counterfactual results for the intensive margin at both the country and city level. The second and third columns of the table report total 2010 traffic between each country and Turkey, as reported by the ICAO data. The fourth column (routes) indicates the number of city pairs for which the database records a flight between the specified country and Turkey. The fifth column reports the level of ALI reported in the WTO database for Turkey's agreement with the country, and the sixth column indicates the change in ALI that we are considering. ${ }^{37}$ The final four columns indicate the predicted change in travel along existing routes, which is 105 to 221 percent. Growth in traffic along city-to-city routes for which direct flights exist is much more modest, 30 to 58 percent depending on the specification.

As the earlier counterfactual estimates suggested, the link between changing ALI and more traffic appears to operate through the extensive margin (more city pairs with direct flights) as well as the intensive margin (more traffic for city pairs for which a flight exists). In Table 7 we illustrate this with estimates of the impact on city-to-city routes associated with the liberalization of commitments that would arise were Turkey and the ACAC to negotiate an agreement with ALI = 50. The second column of Table 7 indicates the number of city pairs that are possible between Turkey, and each ACAC country, if every location that handled international flights in the ACAC country were to share a flight with every location in Turkey that operates an international flight. ${ }^{38}$ The third and fourth columns indicate the benchmark ALI score as well as the change in ALI that we use in our calculations. Columns 5 and 6 show the change in the odds ratio for flights between Turkey and each respective country, using estimates from

\footnotetext{
${ }^{37}$ The ALI governing traffic between Turkey and some ACAC members is not reported in the WTO database, because these countries did not have an existing bilateral arrangement with Turkey at the time these data were collected. We impute these using the passenger-weighted average of each country's ALI with partners from the rest of the world. The weighted ALI average values are calculated and reported by the WTO.

${ }^{38}$ There were 13 such cities in Turkey in 2010.
} 
Table 4, columns 2 and 3. These estimates suggest that the odds of a flight for any given city pair rise by a factor of roughly 1.8 to 3.1 depending on the estimates.

To make these estimates more tangible we use the final four columns of Table 7 to report our estimates of the number of city pairs in which the probability of flight (as predicted by our model) goes from below 0.5 to above 0.5 when we consider the policy change. In Table 7 , we see that new city pairs emerge in many countries. As many as six new flights (to or from Lebanon) are predicted by the estimates in column 2 of Table 4. The estimates from Column 3 are of slightly smaller magnitude, and distributed somewhat differently across countries. Egypt sees the most new city-to-city routes (4) with Turkey under this specification.

\section{Conclusions}

In this study, we estimate a set of empirical models of air passenger traffic, in order to better understand the relationship between air transport policy and international traffic. We use a WTO index measure of policy commitments in both bilateral and plurilateral air services agreements, and relate these measures to ICAO data on air passenger traffic. We find that country pairs with more liberal policy commitments see greater air passenger traffic. Subsequent work at the city level indicates that larger passenger numbers in more liberal agreements occur because there is higher traffic on existing routes and because more city pairs are served by a flight.

We use our empirical models to investigate the likely impact of two policy changes. First, we consider the impact of deepening the ACAC agreement, awarding it the same policy score as the UKSingapore bilateral agreement. Because policy within the ACAC is already fairly liberal, the deepening of the agreement has modest, but significant effects. Our estimates suggest a 30 percent increase in traffic between ACAC countries as a result of the policy change.

In a second scenario we add Turkey to the deeper ACAC agreement, assigning the same liberal measures to Turkey-ACAC passenger flows. Due to the restrictive nature of policy commitments between Turkey and many Arab countries, this scenario generates much more growth in passenger traffic. 
Our estimates suggest that passenger traffic would more than double. Much of this would arise through increasing numbers of direct flights between Turkish cities and cities in the ACAC member states.

While these results may seem optimistic, there are three reasons to suggest they are not unrealistic. First, current air passenger traffic levels in the region are low, and fast growth is plausible off a small base. Second, much faster growth rates have been observed in recent years in selected regional markets. Finally, the policy changes we consider are large, with the Turkey-ACAC policies changing quite substantially in our second scenario.

Our results should be understood as preliminary work that scopes out the possibilities associated with further reform in the region. Air policy liberalizations in the United States and Europe have generated a rich set of responses that we do not model here, such as changing network structures and the growth of low-cost carriers. These could be considered as possible channels for the effects that we estimate. The deep liberalization scenarios that we consider might be expected to produce important changes in market structure, airline networks, and the number and type of carriers serving Middle East air markets. Responses like these are likely to be specific to the institutions and geography of the Middle East, and are therefore difficult to anticipate.

\section{References}

Anderson, J. E., and E. van Wincoop, 2003. "Gravity with Gravitas: A Solution to the Border Puzzle." The American Economic Review 93, pp. 170-192.

Bergstrand, Jeffrey, 1985. "The gravity equation in international trade: some microeconomic foundations and empirical evidence", The Review of Economics and Statistics, pp. 474-481.

Bilotkach, V., 2007. Price Effects of Airline Consolidation: Evidence from a Sample of Transatlantic Markets. Empirical Economics 33, 427-448.

Booz Allen Hamilton (2007) The Economic Impacts of an Open Aviation Area between the EU and US, http://ec.europa.eu/transport/modes/air/international_aviation/country_index/doc/final_report_us_bah.pdf, accessed April 13, 2005.

Brainard, Lael, 1997. “An Assessment of the Proximity-Concentration Trade-Off between Multinational Sales and Trade”, American Economic Review 87, pp. 520-544. 
Brueckner, J., Whalen, T., 2000. The Price Effects of International Airline Alliances. Journal of Law and Economics XLIII, 503-545.

Brueckner, J., 2003. International Airfares in the Age of Alliances: The Effects of Code Sharing and Antitrust Immunity. Review of Economics and Statistics 85, 105-118.

Cristea, Anca D, 2011. "Buyer-seller relationships in international trade: Evidence from US States' exports and business-class travel." Journal of International Economics 84, pp. 207-220.

Cristea, A., Hummels, D., Roberson, B., 2012. Estimating the Gains from Liberalizing Services Trade: The Case of Passenger Aviation. University of Oregon, mimeo.

Dobruszkes, F. (2009). Does liberalisation of air transport imply increasing competition? Lessons from the European case. Transport Policy, 16(1), 29-39.

Doove, Samantha, Owen Gabbitas, Duc Nguyen-Hong and Joe Owen. 2001. "Price Effects of Regulation: International Air Passenger Transport, Telecommunications and Electricity Supply,” Australia Productivity Commission Staff Research Paper.

Fu, X., Oum, T. H., \& Zhang, A. (2010). Air transport liberalization and its impacts on airline competition and air passenger traffic. Transportation Journal, 24-41.

Gonenc, R., Nicoletti, G., 2001. Regulation, Market Structure and Performance in Air Passenger Transportation. OECD Economic Studies 32, 183-227.

Head, K., Mayer, T. \& Ries, J. (2010), “The erosion of colonial trade linkages after independence” Journal of International Economics, 81(1):1-14.

InterVISTAS (2006), The Economic Impact of Air Service Liberalization, http://www.intervistas.com/downloads/Economic Impact of Air Service Liberalization Final Report.p df accessed April 13, 2015.

International Civil Aviation Organisation (ICAO), 2004. Manual on the Regulation of International Air Transport (2nd ed.). Montreal: ICAO.

Jia, Y., Winston, C., 2012. Open Skies: Estimating the Benefits of Free Trade in Airline Services. Washington State University, mimeo.

Karemera, D., Oguledo, V. I., and Davis, B., 2000. “A gravity model analysis of international migration to North America”, Applied Economics 32(13), pp. 1745-1755.

Micco, A., Serebrisky, T., 2006. Competition Regimes and Air Transport Costs: The Effects of Open Skies Agreements. Journal of International Economics 70, 25-51.

Neiman, Brent, and Phillip Swagel, 2009. "The impact of post-9/11 visa policies on travel to the United States." Journal of International Economics 78, pp. 86-99.

Piermartini, R., Rousova, L., 2012. The Sky is Not Flat: How Discriminatory is the Access to International Air Services? American Economics Journal: Economic Policy, forthcoming. 
Poole, Jennifer P., 2010. "Business Travel as an Input to International Trade”, University of California, Santa Cruz, mimeo.

Portes, Richard, and Helene Rey, 2005. "The determinants of cross-border equity flows." Journal of international Economics 65, pp. 269-296.

Rauch, James, 1999, “Networks Versus Markets in International Trade,” Journal of International Economics 48, pp. 7-35.

Santos Silva, JMC and Silvana Tenreyro, 2006. "The log of gravity", The Review of Economics and Statistics 88, pp. 641-658.

Schipper, Youdi, Piet Rietveld, and Peter Nijkamp (2002) European Airline Reform: An Empirical Welfare Analysis, Journal of Transport Economics and Policy, Volume 36, Part 2, pp. 189 209

Schlumberger, Charles, 2010, Open Skies for Africa: Implementing the Yamoussoukro Decision. Washington, DC: World Bank.

Tinbergen, Jan, 1962. Shaping the World Economy: Suggestions for an International Economic Policy. New York: Twentieth Century Fund.

Whalen, W. T., 2007. A Panel Data Analysis of Code-sharing, Antitrust Immunity, and Open Skies Treaties in International Aviation Markets. Review of Industrial Organization 30, 39-61.

World Trade Organization (2007), Second Review of the Air Transport Annex: Developments in the Air Transport Sector, Note by the Secretariat, S/C/W/270/Add.1 and Add.2, September 28, 2007, WTO, Geneva. 
Table 1. Origin-destination traffic, 2000-2010 (thousands)

\begin{tabular}{|c|c|c|c|c|}
\hline Origin & Destination & 2000 & 2010 & $\%$ growth $00-10$ \\
\hline \multirow[t]{10}{*}{ Turkey } & Egypt & 39.5 & 190.7 & 383 \\
\hline & Jordan & 14.5 & 108.7 & 650 \\
\hline & Lebanon & 9.0 & 78.5 & 772 \\
\hline & Morocco & 0.0 & 54.2 & \\
\hline & Qatar & 0.0 & 32.5 & \\
\hline & Saudi Arabia & 22.5 & 315.1 & 1300 \\
\hline & Tunisia & 38.6 & 76.7 & 99 \\
\hline & UAE & 30.2 & 322.3 & 967 \\
\hline & Rest of ACAC & 50.2 & 452.8 & 802 \\
\hline & Rest of World & $2,891.8$ & $8,703.8$ & 201 \\
\hline \multirow[t]{10}{*}{ Egypt } & Turkey & 38.7 & 188.3 & 387 \\
\hline & Jordan & 25.4 & 211.2 & 731 \\
\hline & Lebanon & 32.0 & 67.2 & 110 \\
\hline & Morocco & 9.7 & 33.2 & 242 \\
\hline & Qatar & 14.5 & 54.5 & 276 \\
\hline & Saudi Arabia & 215.6 & $1,558.6$ & 623 \\
\hline & Tunisia & 17.5 & 36.2 & 107 \\
\hline & UAE & 105.5 & 420.6 & 299 \\
\hline & Rest of ACAC & 101.4 & 938.9 & 826 \\
\hline & Rest of World & $1,220.0$ & $3,124.6$ & 156 \\
\hline \multirow[t]{10}{*}{ Jordan } & Turkey & 10.0 & 112.2 & 1022 \\
\hline & Egypt & 26.8 & 203.0 & 657 \\
\hline & Lebanon & 0.0 & 88.9 & \\
\hline & Morocco & 0.0 & 0.0 & \\
\hline & Qatar & 0.0 & 14.8 & \\
\hline & Saudi Arabia & 0.0 & 211.6 & \\
\hline & Tunisia & 3.4 & 9.8 & 188 \\
\hline & UAE & 24.2 & 261.5 & 981 \\
\hline & Rest of ACAC & S & 304.5 & \\
\hline & Rest of World & 136.1 & 813.6 & 498 \\
\hline \multirow[t]{10}{*}{ Saudi Arabia } & Turkey & 23.7 & 323.2 & 1264 \\
\hline & Egypt & 228.6 & $1,538.3$ & 573 \\
\hline & Jordan & 0.0 & 208.3 & \\
\hline & Lebanon & 0.0 & 61.0 & \\
\hline & Morocco & 0.0 & 60.2 & \\
\hline & Qatar & S & 23.0 & \\
\hline & Tunisia & 30.7 & 45.4 & 48 \\
\hline & UAE & 79.4 & 769.5 & 869 \\
\hline & Rest of ACAC & 3.1 & 700.4 & 22494 \\
\hline & Rest of World & $1,129.3$ & $2,961.9$ & 162 \\
\hline \multirow[t]{10}{*}{ Tunisia } & Turkey & 38.0 & 83.5 & 120 \\
\hline & Egypt & 17.4 & 35.3 & 103 \\
\hline & Jordan & 2.8 & 10.2 & 264 \\
\hline & Lebanon & 2.9 & 9.8 & 238 \\
\hline & Morocco & 26.4 & 28.2 & 7 \\
\hline & Qatar & 0 & 0 & \\
\hline & Saudi Arabia & 22.9 & 45.7 & 100 \\
\hline & UAE & 0.7 & 60.6 & 8557 \\
\hline & Rest of ACAC & 32.4 & 144.2 & 345 \\
\hline & Rest of World & $1,151.9$ & $1,397.4$ & 21 \\
\hline \multirow[t]{10}{*}{ UAE } & Turkey & 32.5 & 317.2 & 876 \\
\hline & Egypt & 101.9 & 418.6 & 311 \\
\hline & Jordan & 24.2 & 259.9 & 974 \\
\hline & Lebanon & 17.1 & 153.2 & 796 \\
\hline & Morocco & 0.0 & 79.1 & \\
\hline & Qatar & 47.5 & 267.3 & 463 \\
\hline & Saudi Arabia & 76.3 & 765.1 & 903 \\
\hline & Tunisia & 0.7 & 60.4 & 8529 \\
\hline & Rest of ACAC & 125.2 & 1,429.1 & 1041 \\
\hline & Rest of World & $2,800.6$ & $15,860.5$ & 466 \\
\hline
\end{tabular}

Passenger travel as reported in ICAO on-flight origin and destination database. "S" indicates data suppressed. 
Table 2: Gravity Equation for Bilateral Passenger Flows using Country Level Air Traffic Data

\begin{tabular}{|c|c|c|c|c|}
\hline Dependent Variable: & \multicolumn{3}{|c|}{$\log (\operatorname{Pax})$} & \multirow{3}{*}{$\begin{array}{l}\text { Pax } \geq \mathbf{0} \\
\text { Poisson } \\
\text { ALL Pluri }\end{array}$} \\
\hline Methodology: & OLS & OLS & OLS & \\
\hline & Basic & ALI Pluri & Extended & \\
\hline & (1) & $(2)$ & (3) & (4) \\
\hline ALI & $\begin{array}{r}0.018 * * * \\
(0.003)\end{array}$ & $\begin{array}{r}0.021^{* * *} \\
(0.005)\end{array}$ & $\begin{array}{r}0.026 * * * \\
(0.005)\end{array}$ & $\begin{array}{r}0.030 * * * \\
(0.006)\end{array}$ \\
\hline Plurilateral ASA & & $\begin{array}{r}-0.148 \\
(0.152)\end{array}$ & $\begin{array}{r}0.094 \\
(0.153)\end{array}$ & $\begin{array}{r}0.060 \\
(0.148)\end{array}$ \\
\hline Log ASA age & $\begin{array}{r}0.003 \\
(0.043)\end{array}$ & $\begin{array}{r}0.000 \\
(0.043)\end{array}$ & $\begin{array}{r}0.021 \\
(0.042)\end{array}$ & $\begin{array}{r}0.046 \\
(0.055)\end{array}$ \\
\hline Log distance & $\begin{array}{r}3.445^{* * *} \\
(0.529)\end{array}$ & $\begin{array}{r}3.499 * * * \\
(0.535)\end{array}$ & $\begin{array}{r}2.120 * * * \\
(0.546)\end{array}$ & $\begin{array}{r}4.859 * * * \\
(0.624)\end{array}$ \\
\hline Log distance squared & $\begin{array}{r}-0.245^{* * *} \\
(0.033)\end{array}$ & $\begin{array}{r}-0.249 * * * \\
(0.034)\end{array}$ & $\begin{array}{r}-0.160 * * * \\
(0.036)\end{array}$ & $\begin{array}{r}-0.336 * * * \\
(0.040)\end{array}$ \\
\hline Log origin country population & $\begin{array}{r}0.063 \\
(0.041)\end{array}$ & $\begin{array}{r}0.064 \\
(0.041)\end{array}$ & $\begin{array}{r}0.038 \\
(0.044)\end{array}$ & $\begin{array}{r}0.019 \\
(0.059)\end{array}$ \\
\hline Log origin GDP & $\begin{array}{r}0.299 * * * \\
(0.035)\end{array}$ & $\begin{array}{r}0.297 * * * \\
(0.035)\end{array}$ & $\begin{array}{r}0.090 \\
(0.060)\end{array}$ & $\begin{array}{r}0.185^{* *} \\
(0.080)\end{array}$ \\
\hline Log destination country population & $\begin{array}{r}0.048 \\
(0.039)\end{array}$ & $\begin{array}{r}0.049 \\
(0.039)\end{array}$ & $\begin{array}{r}0.007 \\
(0.040)\end{array}$ & $\begin{array}{r}-0.029 \\
(0.047)\end{array}$ \\
\hline Log destination GDP & $\begin{array}{r}0.372 * * * \\
(0.031)\end{array}$ & $\begin{array}{r}0.370^{* * *} \\
(0.031)\end{array}$ & $\begin{array}{r}0.197^{* * *} \\
(0.055)\end{array}$ & $\begin{array}{r}0.265^{* * *} \\
(0.071)\end{array}$ \\
\hline Log trade & $\begin{array}{r}0.291^{* * *} \\
(0.026)\end{array}$ & $\begin{array}{r}0.290 * * * \\
(0.026)\end{array}$ & $\begin{array}{r}0.223^{* * *} \\
(0.026)\end{array}$ & $\begin{array}{r}0.285 * * * \\
(0.039)\end{array}$ \\
\hline Border & $\begin{array}{r}0.111 \\
(0.112)\end{array}$ & $\begin{array}{r}0.116 \\
(0.112)\end{array}$ & $\begin{array}{r}-0.088 \\
(0.107)\end{array}$ & $\begin{array}{r}-0.117 \\
(0.134)\end{array}$ \\
\hline Common colony & $\begin{array}{r}0.890 * * * \\
(0.090)\end{array}$ & $\begin{array}{r}0.872 * * * \\
(0.093)\end{array}$ & $\begin{array}{r}1.102^{* * *} \\
(0.095)\end{array}$ & $\begin{array}{r}0.646^{* * *} \\
(0.112)\end{array}$ \\
\hline Common language & $\begin{array}{r}0.469 * * * \\
(0.080)\end{array}$ & $\begin{array}{r}0.486 * * * \\
(0.084)\end{array}$ & $\begin{array}{r}0.344 * * * \\
(0.081)\end{array}$ & $\begin{array}{r}0.130 \\
(0.101)\end{array}$ \\
\hline Log area, origin country & $\begin{array}{r}-0.110 * * * \\
(0.023)\end{array}$ & $\begin{array}{r}-0.109 * * * \\
(0.023)\end{array}$ & $\begin{array}{r}-0.117 * * * \\
(0.025)\end{array}$ & $\begin{array}{r}-0.105^{* * *} \\
(0.031)\end{array}$ \\
\hline Log area, destination country & $\begin{array}{r}-0.115^{* * *} \\
(0.022)\end{array}$ & $\begin{array}{r}-0.114^{* * *} \\
(0.022)\end{array}$ & $\begin{array}{r}-0.120^{* * *} \\
(0.022)\end{array}$ & $\begin{array}{r}-0.096 * * * \\
(0.027)\end{array}$ \\
\hline Europe indicator & $\begin{array}{r}-0.915 * * * \\
(0.138)\end{array}$ & $\begin{array}{r}-0.914 * * * \\
(0.138)\end{array}$ & $\begin{array}{r}-0.804 * * * \\
(0.134)\end{array}$ & $\begin{array}{r}-0.710^{* * *} \\
(0.157)\end{array}$ \\
\hline RTA & & & $\begin{array}{r}0.256 * * * \\
(0.074)\end{array}$ & $\begin{array}{r}0.300 * * * \\
(0.102)\end{array}$ \\
\hline Both WTO members & & & $\begin{array}{r}0.104 \\
(0.084)\end{array}$ & $\begin{array}{r}0.590^{* * *} \\
(0.122)\end{array}$ \\
\hline Trade share in differentiated goods & & & $\begin{array}{r}0.080 \\
(0.129)\end{array}$ & $\begin{array}{r}-0.245 \\
(0.157)\end{array}$ \\
\hline Both democracies & & & $\begin{array}{r}-0.118^{*} \\
(0.067)\end{array}$ & $\begin{array}{r}-0.115 \\
(0.094)\end{array}$ \\
\hline Log temperature difference & & & $\begin{array}{r}0.026 \\
(0.026)\end{array}$ & $\begin{array}{r}0.031 \\
(0.039)\end{array}$ \\
\hline Log time difference & & & $\begin{array}{r}-0.112 * * \\
(0.054)\end{array}$ & $\begin{array}{r}-0.012 \\
(0.101)\end{array}$ \\
\hline Avg. ALI across all partners by origin country & & & $\begin{array}{r}-0.020 * * * \\
(0.003)\end{array}$ & $\begin{array}{r}-0.016^{* * *} \\
(0.006)\end{array}$ \\
\hline Avg. ALI across all partners by destination country & & & $\begin{array}{r}-0.025^{* * *} \\
(0.004)\end{array}$ & $\begin{array}{r}-0.021 * * * \\
(0.005)\end{array}$ \\
\hline Log departures worldwide (origin country) & & & $\begin{array}{r}0.308 * * * \\
(0.057)\end{array}$ & $\begin{array}{r}0.290 * * * \\
(0.092)\end{array}$ \\
\hline Log departures worldwide (destination country) & & & $0.267 * * *$ & $0.239 * * *$ \\
\hline
\end{tabular}


Observations

\section{Counterfactual Scenario}

$\%$ change if ACAC liberalizes fully $(A L I=50)$

$21.9 \quad 26.0$

33.1

39.1

Robust standard errors in parentheses ${ }^{* * *} \mathrm{p}<0.01,{ }^{* *} \mathrm{p}<0.05$, ${ }^{*} \mathrm{p}<0.1$

Notes: The results reported in this table are obtained by estimating the regression model given by equation (1) in the text. The unit of observation is a country pair. The dependent variable is the number of air passengers traveling between two countries. 
Table 3: Gravity Equation for Bilateral Passenger Flows using City-Pair Air Traffic Data

\begin{tabular}{|c|c|c|c|c|}
\hline Dependent variable: & \multicolumn{3}{|c|}{$\log ($ Pax) } & \multirow{3}{*}{$\begin{array}{r}\text { Pax } \geq \mathbf{0} \\
\text { Poisson } \\
\text { ALL Pluri }\end{array}$} \\
\hline Methodology: & OLS & OLS & OLS & \\
\hline & Basic & ALI Pluri & Extended & \\
\hline & (1) & $(2)$ & (3) & (4) \\
\hline ALI & $\begin{array}{r}0.006^{* *} \\
(0.003)\end{array}$ & $\begin{array}{r}0.013^{* * *} \\
(0.004)\end{array}$ & $\begin{array}{r}0.015^{* * *} \\
(0.005)\end{array}$ & $\begin{array}{r}0.010^{* *} \\
(0.004)\end{array}$ \\
\hline Plurilateral ASA & & $\begin{array}{r}-0.273 * * \\
(0.135)\end{array}$ & $\begin{array}{r}-0.159 \\
(0.143)\end{array}$ & $\begin{array}{r}0.181 \\
(0.139)\end{array}$ \\
\hline Log ASA age & $\begin{array}{r}0.053 \\
(0.041)\end{array}$ & $\begin{array}{r}0.039 \\
(0.044)\end{array}$ & $\begin{array}{r}0.015 \\
(0.045)\end{array}$ & $\begin{array}{c}0.088 * \\
(0.046)\end{array}$ \\
\hline Log city distance & $\begin{array}{r}1.395^{* * *} \\
(0.394)\end{array}$ & $\begin{array}{r}1.418^{* * *} \\
(0.402)\end{array}$ & $\begin{array}{r}1.123 * * * \\
(0.400)\end{array}$ & $\begin{array}{r}1.279 * * * \\
(0.407)\end{array}$ \\
\hline Log city distance squared & $\begin{array}{r}-0.115^{* * *} \\
(0.025)\end{array}$ & $\begin{array}{r}-0.117^{* * *} \\
(0.026)\end{array}$ & $\begin{array}{r}-0.098 * * * \\
(0.027)\end{array}$ & $\begin{array}{r}-0.102^{* * *} \\
(0.029)\end{array}$ \\
\hline Log departure city population & $\begin{array}{r}0.269 * * * \\
(0.028)\end{array}$ & $\begin{array}{r}0.266^{* * *} \\
(0.028)\end{array}$ & $\begin{array}{r}0.261^{* * *} \\
(0.028)\end{array}$ & $\begin{array}{r}0.377^{* * *} \\
(0.031)\end{array}$ \\
\hline Log departure country per-capita GDP & $\begin{array}{r}0.183^{* * *} \\
\quad(0.032)\end{array}$ & $\begin{array}{r}0.182^{* * *} \\
\quad(0.032)\end{array}$ & $\begin{array}{r}0.211^{* * *} \\
(0.035)\end{array}$ & $\begin{array}{r}0.227 * * * \\
(0.042)\end{array}$ \\
\hline Log arrival city population & $\begin{array}{r}0.269 * * * \\
(0.026)\end{array}$ & $\begin{array}{r}0.267 * * * \\
(0.026)\end{array}$ & $\begin{array}{r}0.263^{* * *} \\
(0.026)\end{array}$ & $\begin{array}{r}0.369 * * * \\
(0.029)\end{array}$ \\
\hline Log arrival country per-capita GDP & $\begin{array}{r}0.223^{* * *} \\
(0.030)\end{array}$ & $\begin{array}{r}0.221^{* * *} \\
\quad(0.029)\end{array}$ & $\begin{array}{r}0.247^{* * *} \\
(0.032)\end{array}$ & $\begin{array}{r}0.259 * * * \\
(0.036)\end{array}$ \\
\hline Log departure country population & $\begin{array}{r}0.091^{* *} \\
(0.039)\end{array}$ & $\begin{array}{r}0.099 * * \\
(0.039)\end{array}$ & $\begin{array}{r}0.121^{* * *} \\
(0.045)\end{array}$ & $\begin{array}{r}-0.012 \\
(0.076)\end{array}$ \\
\hline Log arrival country population & $\begin{array}{r}0.126 * * * \\
(0.039)\end{array}$ & $\begin{array}{r}0.133^{* * *} \\
(0.039)\end{array}$ & $\begin{array}{r}0.147^{* * *} \\
(0.042)\end{array}$ & $\begin{array}{r}0.025 \\
(0.051)\end{array}$ \\
\hline Log trade & $\begin{array}{r}0.127 * * * \\
(0.024)\end{array}$ & $\begin{array}{r}0.118 * * * \\
(0.024)\end{array}$ & $\begin{array}{r}0.083^{* * *} \\
(0.025)\end{array}$ & $\begin{array}{r}0.124 * * * \\
(0.032)\end{array}$ \\
\hline Departure city route share x Log world departures & $\begin{array}{r}0.128 * * * \\
(0.011)\end{array}$ & $\begin{array}{r}0.130 * * * \\
(0.011)\end{array}$ & $\begin{array}{r}0.138 * * * \\
(0.011)\end{array}$ & $\begin{array}{r}0.092 * * * \\
(0.014)\end{array}$ \\
\hline Arrival city route share $x$ Log world departures & $\begin{array}{r}0.148^{* * *} \\
(0.012)\end{array}$ & $\begin{array}{r}0.148 * * * \\
(0.011)\end{array}$ & $\begin{array}{r}0.155^{* * *} \\
(0.011)\end{array}$ & $\begin{array}{r}0.108 * * * \\
(0.009)\end{array}$ \\
\hline Border & $\begin{array}{r}-0.195^{* *} \\
(0.085)\end{array}$ & $\begin{array}{r}-0.194^{* *} \\
(0.084)\end{array}$ & $\begin{array}{r}-0.228 * * \\
(0.090)\end{array}$ & $\begin{array}{r}-0.245^{* * *} \\
(0.072)\end{array}$ \\
\hline Common colony & $\begin{array}{r}0.538 * * * \\
(0.099)\end{array}$ & $\begin{array}{r}0.548 * * * \\
(0.100)\end{array}$ & $\begin{array}{r}0.623 * * * \\
(0.102)\end{array}$ & $\begin{array}{r}0.507 * * * \\
(0.105)\end{array}$ \\
\hline Common language & $\begin{array}{c}0.125 * \\
(0.072)\end{array}$ & $\begin{array}{c}0.141 * \\
(0.073)\end{array}$ & $\begin{array}{r}0.092 \\
(0.079)\end{array}$ & $\begin{array}{r}0.034 \\
(0.085)\end{array}$ \\
\hline Log area, departure country & $\begin{array}{r}-0.065^{* *} \\
(0.026)\end{array}$ & $\begin{array}{r}-0.069 * * * \\
(0.026)\end{array}$ & $\begin{array}{r}-0.055^{*} \\
(0.030)\end{array}$ & $\begin{array}{r}-0.010 \\
(0.025)\end{array}$ \\
\hline Log area, arrival country & $\begin{array}{r}-0.040 \\
(0.025)\end{array}$ & $\begin{array}{r}-0.045^{*} \\
(0.025)\end{array}$ & $\begin{array}{r}-0.030 \\
(0.028)\end{array}$ & $\begin{array}{r}-0.005 \\
(0.023)\end{array}$ \\
\hline Europe indicator & $\begin{array}{r}-0.074 \\
(0.121)\end{array}$ & $\begin{array}{r}-0.047 \\
(0.123)\end{array}$ & $\begin{array}{r}-0.105 \\
(0.117)\end{array}$ & $\begin{array}{r}0.070 \\
(0.121)\end{array}$ \\
\hline RTA & & & $\begin{array}{r}0.253^{* * *} \\
(0.097)\end{array}$ & $\begin{array}{r}0.145 \\
(0.096)\end{array}$ \\
\hline Both WTO members & & & $\begin{array}{r}0.268^{* * *} \\
(0.101)\end{array}$ & $\begin{array}{r}0.810^{* * *} \\
(0.091)\end{array}$ \\
\hline Trade share in differentiated goods & & & $\begin{array}{r}-0.006 \\
(0.140)\end{array}$ & $\begin{array}{r}-0.167 \\
(0.127)\end{array}$ \\
\hline Both democracies & & & $\begin{array}{r}-0.135^{*} \\
(0.071)\end{array}$ & $\begin{array}{r}-0.217^{* *} \\
(0.089)\end{array}$ \\
\hline Log temperature difference & & & $\begin{array}{r}0.043 \\
(0.027)\end{array}$ & $\begin{array}{r}-0.016 \\
(0.031)\end{array}$ \\
\hline Log time difference & & & $\begin{array}{r}0.011 \\
(0.064)\end{array}$ & $\begin{array}{r}0.122^{* *} \\
(0.058)\end{array}$ \\
\hline
\end{tabular}


Avg. ALI across all partners by country of departure

\begin{tabular}{rrrr} 
& & $-0.007^{*}$ & $-0.006^{*}$ \\
& & $(0.004)$ & $(0.004)$ \\
& & $-0.008^{*}$ & $-0.009^{* *}$ \\
& & $(0.004)$ & $(0.004)$ \\
8,295 & 8,295 & 8,291 & 8,291 \\
0.27 & 0.27 & 0.27 & n.a. \\
\hline & & & \\
6.8 & 15.4 & 17.9 & 11.6 \\
\hline
\end{tabular}

Avg. ALI across all partners by country of arrival

Observations

R-squared

Counterfactual Scenario

$\%$ change if ACAC liberalizes fully (ALI $=50)$

Robust standard errors in parentheses, ${ }^{* * *} \mathrm{p}<0.01,{ }^{* *} \mathrm{p}<0.05,{ }^{*} \mathrm{p}<0.1$

Notes: The results reported in this table are obtained by estimating the regression model given by equation (1) in the text. The unit of observation is a city pair. The dependent variable is the number of air passengers traveling between two countries. 
Table 4: Likelihood of Market Entry for Direct Air Service at City-Pair Level

\begin{tabular}{|c|c|c|c|}
\hline \multirow{3}{*}{$\begin{array}{r}\text { Dependent variable: } \\
\text { Methodology: } \\
\text { Model Specification: }\end{array}$} & \multicolumn{3}{|c|}{$\operatorname{Pr}(\operatorname{Pax}>0)$} \\
\hline & Logit & Logit & Logit \\
\hline & Basic & ALI Pluri & Extended \\
\hline & (1) & $(2)$ & (3) \\
\hline \multirow[t]{2}{*}{ ALI } & $0.025 * * *$ & $0.031 * * *$ & $0.019 * * *$ \\
\hline & $(0.004)$ & $(0.005)$ & $(0.005)$ \\
\hline \multirow[t]{2}{*}{ Plurilateral ASA } & & $-0.286 *$ & -0.104 \\
\hline & & $(0.160)$ & $(0.155)$ \\
\hline \multirow[t]{2}{*}{ Log ASA age } & $0.089 *$ & 0.073 & 0.007 \\
\hline & $(0.051)$ & $(0.053)$ & $(0.050)$ \\
\hline \multirow[t]{2}{*}{ Log city distance } & $4.682^{* * *}$ & $4.764^{* * *}$ & $4.382 * * *$ \\
\hline & $(0.405)$ & $(0.410)$ & (0.389) \\
\hline \multirow[t]{2}{*}{ Log city distance squared } & $-0.372 * * *$ & $-0.378 * * *$ & $-0.358 * * *$ \\
\hline & $(0.026)$ & $(0.027)$ & $(0.027)$ \\
\hline \multirow[t]{2}{*}{ Log departure city population } & $0.491 * * *$ & $0.491^{* * *}$ & $0.533 * * *$ \\
\hline & $(0.032)$ & $(0.032)$ & (0.035) \\
\hline \multirow[t]{2}{*}{ Log departure country per-capita GDP } & $0.219 * * *$ & $0.217 * * *$ & $0.263 * * *$ \\
\hline & $(0.046)$ & $(0.045)$ & $(0.046)$ \\
\hline \multirow[t]{2}{*}{ Log arrival city population } & $0.487 * * *$ & $0.487 * * *$ & $0.510 * * *$ \\
\hline & $(0.034)$ & $(0.034)$ & $(0.036)$ \\
\hline \multirow[t]{2}{*}{ Log arrival country per-capita GDP } & $0.232 * * *$ & $0.230 * * *$ & $0.288 * * *$ \\
\hline & $(0.040)$ & $(0.040)$ & $(0.042)$ \\
\hline \multirow[t]{2}{*}{ Log departure country population } & -0.035 & -0.031 & -0.049 \\
\hline & $(0.048)$ & $(0.048)$ & $(0.052)$ \\
\hline \multirow[t]{2}{*}{ Log arrival country population } & -0.047 & -0.043 & -0.012 \\
\hline & $(0.051)$ & $(0.051)$ & $(0.050)$ \\
\hline \multirow[t]{2}{*}{ Log trade } & $0.272 * * *$ & $0.264 * * *$ & $0.195 * * *$ \\
\hline & $(0.029)$ & $(0.028)$ & (0.029) \\
\hline \multirow[t]{2}{*}{ Departure city route share x Log world departures } & $0.270 * * *$ & $0.269 * * *$ & $0.267 * * *$ \\
\hline & $(0.012)$ & (0.011) & $(0.011)$ \\
\hline \multirow[t]{2}{*}{ Arrival city route share $x$ Log world departures } & $0.261 * * *$ & $0.260 * * *$ & $0.264 * * *$ \\
\hline & $(0.012)$ & $(0.012)$ & $(0.012)$ \\
\hline \multirow[t]{2}{*}{ Border } & -0.115 & -0.132 & $-0.274 * *$ \\
\hline & $(0.116)$ & $(0.118)$ & $(0.112)$ \\
\hline \multirow[t]{2}{*}{ Common colony } & $0.403 * * *$ & $0.441 * * *$ & $0.553 * * *$ \\
\hline & $(0.136)$ & (0.139) & $(0.136)$ \\
\hline \multirow[t]{2}{*}{ Common language } & $0.544 * * *$ & $0.546 * * *$ & $0.481 * * *$ \\
\hline & $(0.093)$ & $(0.092)$ & $(0.091)$ \\
\hline \multirow[t]{2}{*}{ Log area, departure country } & 0.021 & 0.015 & $0.088^{* * *}$ \\
\hline & $(0.027)$ & $(0.027)$ & $(0.028)$ \\
\hline Log area, arrival country & 0.014 & 0.007 & $0.047^{*}$ \\
\hline & $(0.027)$ & $(0.027)$ & $(0.027)$ \\
\hline Europe indicator & $-0.644 * * *$ & $-0.624 * * *$ & $-0.524 * * *$ \\
\hline & $(0.205)$ & $(0.207)$ & $(0.192)$ \\
\hline RTA & & & $0.349 * * *$ \\
\hline & & & (0.099) \\
\hline Both WTO members & & & $1.067 * * *$ \\
\hline & & & $(0.134)$ \\
\hline Trade share in differentiated goods & & & $0.277^{*}$ \\
\hline & & & $(0.150)$ \\
\hline Both democracies & & & $-0.278 * * *$ \\
\hline & & & $(0.073)$ \\
\hline Log temperature difference & & & $0.057^{*}$ \\
\hline & & & $(0.029)$ \\
\hline Log time difference & & & -0.004 \\
\hline
\end{tabular}


Avg. ALI across all partners by country of departure

Avg. ALI across all partners by country of arrival

Observations

447,992

447,992

447,871

Pseudo R-squared

Counterfactual Scenario

1.3

1.4

1.2

$\%$ change if ACAC liberalizes fully (ALI $=50$ )

Robust standard errors in parentheses, ${ }^{* * *} \mathrm{p}<0.01,{ }^{* *} \mathrm{p}<0.05,{ }^{*} \mathrm{p}<0.1$

Notes: The reported results are obtained by estimating the regression model given by equation (3) in the text. The unit of observation is a city pair. The dependent variable is an indicator variable equal to 1 if the two cities are connected by direct scheduled air service. 
Table 5: The Impact of Individual ASA Components on Air Services

\begin{tabular}{|c|c|c|c|c|c|c|c|c|c|c|c|c|}
\hline & \multicolumn{6}{|c|}{ Dependent Variable: Log (Pax, Country Level) } & \multicolumn{6}{|c|}{ Dependent variable: $\operatorname{Pr}(\operatorname{Pax}>0)$} \\
\hline & $\begin{array}{l}\text { Flying } \\
\text { Rights }\end{array}$ & Capacity & Pricing & $\begin{array}{r}\text { Owner- } \\
\text { ship }\end{array}$ & Other & All & $\begin{array}{l}\text { Flying } \\
\text { Rights }\end{array}$ & Capacity & Pricing & $\begin{array}{r}\text { Owner- } \\
\text { ship }\end{array}$ & Other & All \\
\hline & $(1)$ & $(2)$ & $(3)$ & $(4)$ & (5) & $(6)$ & $(7)$ & $(8)$ & $(9)$ & $(10)$ & $(11)$ & $(12)$ \\
\hline \multirow[t]{2}{*}{ Plurilateral ASA } & $0.496 * * *$ & $0.346 * * *$ & $0.548 * * *$ & $0.769 * * *$ & $0.481 * * *$ & $0.368^{*}$ & $-0.297 *$ & 0.118 & -0.023 & 0.243 & 0.219 & 0.121 \\
\hline & $(0.137)$ & $(0.134)$ & $(0.196)$ & $(0.141)$ & $(0.114)$ & $(0.208)$ & $(0.152)$ & $(0.150)$ & $(0.158)$ & $(0.240)$ & $(0.144)$ & $(0.270)$ \\
\hline \multirow[t]{2}{*}{$5^{\text {th }}$ Freedom } & $0.422 * * *$ & & & & & $0.333^{* * *}$ & 0.133 & & & & & 0.041 \\
\hline & $(0.083)$ & & & & & $(0.084)$ & $(0.087)$ & & & & & $(0.091)$ \\
\hline \multirow{2}{*}{$7^{\text {th }}$ Freedom + Cabotage } & 0.010 & & & & & -0.205 & $0.686 * * *$ & & & & & $0.629 * * *$ \\
\hline & $(0.133)$ & & & & & $(0.142)$ & $(0.166)$ & & & & & $(0.164)$ \\
\hline \multirow[t]{2}{*}{ Capacity: Bermuda 1} & & 0.086 & & & & -0.077 & & $0.497 * * *$ & & & & $0.552 * * *$ \\
\hline & & $(0.094)$ & & & & $(0.098)$ & & (0.099) & & & & (0.116) \\
\hline \multirow[t]{2}{*}{ Capacity: Free Determination } & & $0.457 * * *$ & & & & 0.143 & & $0.206^{*}$ & & & & -0.093 \\
\hline & & $(0.130)$ & & & & $(0.170)$ & & $(0.111)$ & & & & $(0.127)$ \\
\hline \multirow[t]{2}{*}{ Pricing: Free pricing } & & & 0.310 & & & 0.201 & & & $0.494 * * *$ & & & $0.743^{* * *}$ \\
\hline & & & (0.189) & & & $(0.213)$ & & & $(0.135)$ & & & $(0.148)$ \\
\hline \multirow[t]{2}{*}{ Pricing: Dual Disapproval } & & & $0.469 * * *$ & & & $0.271^{* *}$ & & & $0.305^{* *}$ & & & $0.684 * * *$ \\
\hline & & & $(0.115)$ & & & $(0.130)$ & & & $(0.131)$ & & & $(0.150)$ \\
\hline \multirow[t]{2}{*}{ Pricing: Country of Origin } & & & -0.201 & & & $-0.445^{* *}$ & & & -0.024 & & & $0.343^{*}$ \\
\hline & & & $(0.158)$ & & & $(0.176)$ & & & $(0.170)$ & & & $(0.178)$ \\
\hline \multirow[t]{2}{*}{ Ownership: Principal Place } & & & & 0.105 & & -0.076 & & & & $0.578^{* *}$ & & $0.613^{* * *}$ \\
\hline & & & & $(0.184)$ & & $(0.199)$ & & & & $(0.174)$ & & $(0.187)$ \\
\hline \multirow[t]{2}{*}{ Ownership: Community Interest } & & & & -0.138 & & -0.050 & & & & -0.088 & & -0.366 \\
\hline & & & & $(0.154)$ & & $(0.158)$ & & & & $(0.265)$ & & $(0.281)$ \\
\hline \multirow[t]{2}{*}{ Multiple designation } & & & & & $0.366 * * *$ & $0.364 * * *$ & & & & & $0.609 * * *$ & $0.411^{* * *}$ \\
\hline & & & & & $(0.078)$ & $(0.082)$ & & & & & $(0.093)$ & $(0.101)$ \\
\hline \multirow[t]{2}{*}{ Cooperative Arrangements } & & & & & $0.283^{* * *}$ & $0.168 * *$ & & & & & $-0.241 * *$ & $-0.501 * * *$ \\
\hline & & & & & $(0.078)$ & $(0.085)$ & & & & & $(0.101)$ & (0.118) \\
\hline \multirow[t]{2}{*}{ Exchange of stats } & & & & & 0.036 & -0.008 & & & & & -0.079 & -0.114 \\
\hline & & & & & $(0.073)$ & $(0.078)$ & & & & & $(0.082)$ & $(0.084)$ \\
\hline Observations & 2,074 & 2,074 & 2,074 & 2,074 & 2,074 & 2,074 & 447,871 & 447,871 & 447,871 & 447,871 & 447,871 & 447,871 \\
\hline (Pseudo) R-squared & 0.54 & 0.54 & 0.55 & 0.54 & 0.55 & 0.56 & 0.368 & 0.368 & 0.368 & 0.368 & 0.369 & 0.373 \\
\hline
\end{tabular}

Note: Columns 1-6 report the results obtained by estimating the regression model given by equation (1) in the text using air traffic data at country level. Columns 7-12 report the results obtained by

estimating the regression model given by equation (3) in the text using city level data. All specifications include the full set of control variables and fixed effects used in previous specifications, but for space considerations are omitted from the table. Also, all the estimations account for individual ASA components that are missing or that are codified as "other". These are also omitted from the table for space constraints. 
Table 6: Counterfactual Exercise for the Case of Turkey Joining the Intra-Arab Freedom of the Air Programme at most liberal policy (ALI = 50) Prediction on Air Traffic and Direct Routes

\begin{tabular}{|c|c|c|c|c|c|c|c|c|c|}
\hline & \multicolumn{3}{|c|}{ Bilateral Air Traffic with Turkey } & \multirow{3}{*}{ ALI } & \multirow{3}{*}{$\Delta \mathrm{ALI}$} & \multicolumn{4}{|c|}{ Predicted Change in ... } \\
\hline & Arrivals & Departures & Routes & & & \multicolumn{2}{|c|}{ Pax (Country) } & \multicolumn{2}{|c|}{ Pax (City) } \\
\hline & into Turkey & from Turkey & & & & Col 2 & Col 3 & Col 2 & Col 3 \\
\hline \multicolumn{10}{|c|}{ Panel A: Available ALI+Traffic Data } \\
\hline BAHRAIN & 33368 & 31672 & 2 & 13.0 & 37.0 & 88 & 187 & 23 & 49 \\
\hline EGYPT & 188283 & 190690 & 5 & 4.0 & 46.0 & 127 & 263 & 38 & 70 \\
\hline IRAQ & 34828 & 35484 & 2 & 10.0 & 40.0 & 100 & 211 & 28 & 55 \\
\hline JORDAN & 112227 & 108748 & 2 & 11.0 & 39.0 & 96 & 203 & 26 & 53 \\
\hline LEBANON & 140192 & 140260 & 3 & 11.0 & 39.0 & 96 & 203 & 26 & 53 \\
\hline MOROCCO & 56648 & 54188 & 1 & 6.0 & 44.0 & 117 & 245 & 35 & 65 \\
\hline SYRIAN ARAB REPUBLIC & 131128 & 133440 & 4 & 11.0 & 39.0 & 96 & 203 & 26 & 53 \\
\hline TUNISIA & 83530 & 76687 & 2 & 10.0 & 40.0 & 100 & 211 & 28 & 55 \\
\hline \multicolumn{10}{|l|}{ Panel B: Imputed ALI Data } \\
\hline$\overline{\text { ALGERIA }}$ & 66604 & 64740 & 1 & 6.4 & 43.6 & 116 & 242 & 34 & 64 \\
\hline COMOROS & -- & -- & -- & 6.0 & 44.0 & 117 & 245 & 35 & 65 \\
\hline DJIBOUTI & -- & -- & -- & 10.0 & 40.0 & 100 & 211 & 28 & 55 \\
\hline KUWAIT & 36432 & 35980 & 1 & 8.5 & 41.5 & 106 & 223 & 31 & 59 \\
\hline LIBYA & 20592 & 23684 & 1 & 7.9 & 42.1 & 109 & 229 & 32 & 61 \\
\hline MAURITANIA & -- & -- & -- & 7.5 & 42.5 & 111 & 232 & 32 & 61 \\
\hline QATAR & 33540 & 32452 & 1 & 9.9 & 40.1 & 100 & 212 & 28 & 56 \\
\hline OMAN & 18368 & 18148 & 1 & 9.8 & 40.2 & 100 & 212 & 28 & 56 \\
\hline SAUDI ARABIA & 323155 & 315149 & 22 & 7.1 & 42.9 & 112 & 235 & 33 & 62 \\
\hline SOMALIA & -- & -- & -- & 6.5 & 43.5 & 115 & 240 & 34 & 64 \\
\hline SUDAN & 28060 & 26856 & 2 & 11.3 & 38.7 & 94 & 200 & 26 & 52 \\
\hline UNITED ARAB EMIRATES & 317167 & 322272 & 5 & 12.7 & 37.3 & 89 & 190 & 24 & 49 \\
\hline \multirow[t]{2}{*}{ YEMEN } & 14356 & 12740 & 1 & 5.0 & 45.0 & 122 & 254 & 37 & 68 \\
\hline & & & & \multicolumn{2}{|c|}{ Avg Predicted change } & 105 & 221 & 30 & 58 \\
\hline
\end{tabular}

Note: This table reports counterfactual calculation for the case of an increase in the aviation liberalization index (ALI) between Turkey and each of the member countries of the Intra-Arab Freedom of the Air Programme from the actual ALI level to a value of 50 corresponding to the plurilateral agreement. The predictions for the change in aggregate passengers, number of air services, and city-pair level air traffic are based on regression coefficients reported in Tables 2 and 3 respectively. 
Table 7: Counterfactual Exercise for the Case of Turkey Joining the Intra-Arab Freedom of the Air Programme at current policy (ALI = 50) Entry Probability Predictions

\begin{tabular}{|c|c|c|c|c|c|c|c|c|c|}
\hline \multirow[t]{3}{*}{ ACAC member } & \multirow[t]{3}{*}{$\begin{array}{r}\text { Number of } \\
\text { All Possible } \\
\text { City Pairs }\end{array}$} & \multirow[t]{3}{*}{ ALI } & \multirow[t]{3}{*}{$\Delta \mathrm{ALI}$} & \multicolumn{2}{|c|}{$\begin{array}{l}\text { Predicted } \Delta \text { Odds } \\
\text { Direct Route }\end{array}$} & \multicolumn{4}{|c|}{$\begin{array}{l}\text { Predicted Change in Number of Routes with } \\
\text { Prob(Air Service) } \geq 0.5\end{array}$} \\
\hline & & & & \multirow[t]{2}{*}{ Col 2} & \multirow[t]{2}{*}{ Col 3} & \multicolumn{2}{|c|}{ Col 2} & \multicolumn{2}{|c|}{ Col 3} \\
\hline & & & & & & Counts & Percent (\%) & Counts & Percent (\%) \\
\hline \multicolumn{10}{|l|}{ Panel A: Available ALI+Traffic Data } \\
\hline BAHRAIN & 13 & 13.0 & 37.0 & 2.4 & 1.8 & -- & -- & -- & -- \\
\hline EGYPT & 143 & 4.0 & 46.0 & 3.1 & 2.2 & 3 & 300 & 4 & 114 \\
\hline IRAQ & 39 & 10.0 & 40.0 & 2.6 & 1.9 & 2 & 150 & 0 & -- \\
\hline JORDAN & 26 & 11.0 & 39.0 & 2.5 & 1.9 & 1 & 50 & 1 & 50 \\
\hline LEBANON & 13 & 11.0 & 39.0 & 2.5 & 1.9 & 6 & 275 & 0 & 0 \\
\hline MOROCCO & 78 & 6.0 & 44.0 & 2.9 & 2.1 & 0 & -- & 0 & -- \\
\hline SYRIAN ARAB REPUBLIC & 26 & 11.0 & 39.0 & 2.5 & 1.9 & 2 & 133 & 1 & 50 \\
\hline TUNISIA & 78 & 10.0 & 40.0 & 2.6 & 1.9 & 1 & -- & 1 & 100 \\
\hline \multicolumn{10}{|l|}{ Panel A: Imputed ALI Data } \\
\hline$\overline{\text { ALGERIA }}$ & 13 & 6.4 & 43.6 & 2.9 & 2.1 & 1 & 50 & 0 & 0 \\
\hline COMOROS & 13 & 6.0 & 44.0 & 2.9 & 2.1 & 0 & 0 & 0 & 0 \\
\hline DJIBOUTI & 13 & 10.0 & 40.0 & 2.6 & 1.9 & 0 & 0 & 0 & 0 \\
\hline KUWAIT & 13 & 8.5 & 41.5 & 2.7 & 2.0 & 1 & 50 & 2 & 75 \\
\hline LIBYA & 26 & 7.9 & 42.1 & 2.8 & 2.0 & 5 & 167 & 2 & 67 \\
\hline MAURITANIA & 13 & 7.5 & 42.5 & 2.8 & 2.0 & 0 & 0 & 0 & 0 \\
\hline QATAR & 13 & 9.9 & 40.1 & 2.6 & 1.9 & 1 & 33 & 0 & 0 \\
\hline OMAN & 26 & 9.8 & 40.2 & 2.6 & 1.9 & 1 & 7 & 1 & 3 \\
\hline SAUDI ARABIA & 65 & 7.1 & 42.9 & 2.8 & 2.0 & 3 & 45 & 2 & 23 \\
\hline SOMALIA & -- & 6.5 & 43.5 & 2.9 & 2.1 & -- & -- & -- & -- \\
\hline SUDAN & 26 & 11.3 & 38.7 & 2.5 & 1.9 & 0 & 0 & 0 & 0 \\
\hline UNITED ARAB EMIRATES & 65 & 12.7 & 37.3 & 2.4 & 1.8 & 1 & 9 & 1 & 8 \\
\hline YEMEN & 26 & 5.0 & 45.0 & 3.0 & 2.1 & 1 & 25 & 1 & 25 \\
\hline
\end{tabular}

Note: This table reports counterfactual calculation for the case of an increase in the aviation liberalization index (ALI) between Turkey and each of the member countries of the Intra-Arab Freedom of the Air Programme from the actual ALI level to a value of 50. The predictions for the change in the odds of direct service, and in the number of routes with predicted probabilities of service greater than 50 percent are based on the regression coefficients reported in Table 4. 
Annex Table 1: ACAC: QUASAR-coded provisions

\begin{tabular}{|c|c|c|c|c|c|c|c|c|c|}
\hline Members & $\begin{array}{l}\text { WALI } \\
\text { (STD) }\end{array}$ & $\begin{array}{c}\text { Date of } \\
\text { signature }\end{array}$ & $3^{\text {rd }}$ freedom & $4^{\text {th }}$ freedom & $5^{\text {th }}$ freedom & $6^{\text {th }}$ freedom & $7^{\text {th }}$ freedom & $\begin{array}{c}8^{\text {th }} \\
\text { freedom } \\
\end{array}$ & $\begin{array}{c}9^{\text {th }} \\
\text { freedom } \\
\end{array}$ \\
\hline \multirow{3}{*}{$\begin{array}{l}\text { Algeria } \\
\text { Bahrain } \\
\text { Comoros } \\
\text { Djibouti } \\
\text { Egypt } \\
\text { Iraq } \\
\text { Jordan } \\
\text { Kuwait } \\
\text { Lebanon } \\
\text { Libya } \\
\text { Mauritania } \\
\text { Morocco } \\
\text { Oman } \\
\text { Qatar } \\
\text { Saudi } \\
\text { Arabia } \\
\text { Somalia } \\
\text { Sudan } \\
\text { Syria } \\
\text { Tunisia } \\
\text { UAE } \\
\text { Yemen }\end{array}$} & \multicolumn{2}{|l|}{$\begin{array}{r}6.1 \\
10.2 \\
6.0 \\
10.0 \\
9.5 \\
2.2 \\
12.1\end{array}$} & \multicolumn{5}{|c|}{$\begin{array}{l}\text { Yes within the territory covered by the agreement: } \\
\text { "The air transport company/companies designated in accordance with the } \\
\text { provisions of this agreement shall enjoy the exercise of the following air } \\
\text { transport rights....c) the right to embark and disembark passengers, cargo and } \\
\text { post whether separately or combined to and from any of the territories of the } \\
\text { State Parties" } \\
\text { (Article 4.2c) }\end{array}$} & \multicolumn{2}{|c|}{$\begin{array}{l}\text { No. } \\
\text { "This agreement shall } \\
\text { not impose on the } \\
\text { States Parties the } \\
\text { granting of Domestic } \\
\text { air transport rights" } \\
\text { (Article 4.3) }\end{array}$} \\
\hline & $\begin{array}{r}2.3 \\
9.7 \\
10.3 \\
8.2\end{array}$ & $\begin{array}{c}\text { Date of } \\
\text { entry into } \\
\text { force }\end{array}$ & Withholding & Designation & Capacity & Tariffs & $\begin{array}{c}\text { Other } \\
\text { QUASAR }\end{array}$ & $\begin{array}{c}\text { Tentative } \\
\text { ALI } \\
\text { (STD) }\end{array}$ & $\begin{array}{c}\text { Tentative } \\
\text { type }\end{array}$ \\
\hline & $\begin{array}{r}10.5 \\
7.3 \\
10.7 \\
\\
9.3 \\
6.6 \\
10.0 \\
8.2 \\
9.9 \\
11.3 \\
3.0\end{array}$ & $\begin{array}{l}\text { Immediately } \\
\text { after the } \\
\text { deposit of } \\
\text { the fifth } \\
\text { instrument } \\
\text { of } \\
\text { ratification } \\
\text { (Article 38) }\end{array}$ & $\begin{array}{c}\text { Community } \\
\text { of interest } \\
\text { (Article } 5.2 \mathrm{a} \text { ) }\end{array}$ & $\begin{array}{l}\text { Multidesignation } \\
\text { (Article 5.1) }\end{array}$ & $\begin{array}{c}\text { Free } \\
\text { determination } \\
\text { (Article } 7.1 \text { ) }\end{array}$ & $\begin{array}{c}\text { Free } \\
\text { pricing } \\
\text { subject to } \\
\text { filing (but } \\
\text { not to } \\
\text { approval) } \\
\text { and to } \\
\text { guidelines } \\
\text { to prevent } \\
\text { anti- } \\
\text { competitive } \\
\text { practices } \\
\text { (Article } 8 \\
\text { and Annex } \\
\text { I) } \\
\end{array}$ & $\begin{array}{c}\text { Cooperative } \\
\text { arrangements } \\
\text { (Article 13) } \\
\text { Exchange of } \\
\text { statistics } \\
\text { (Article 18) }\end{array}$ & 39 & G \\
\hline
\end{tabular}

Source: World Trade Organization (2007). 


\section{Annex Table 2: ACAC Relationship with other Air Services Agreements and third parties}

\begin{tabular}{|c|c|c|}
\hline $\begin{array}{l}\text { Air Services Agreements/third parties } \\
\text { concerned }\end{array}$ & Provision & Description or text \\
\hline $\begin{array}{l}\text { Past bilateral ASAs between members of the } \\
\text { plurilateral }\end{array}$ & Article 2.3 & $\begin{array}{l}\text { "The provisions of this Agreement shall supersede any conflicting provisions of the bilateral or } \\
\text { multilateral agreements concluded to regulate air transport between the States Parties. Any } \\
\text { provisions of such agreements that are not stipulated in this Agreement shall remain in force." }\end{array}$ \\
\hline $\begin{array}{l}\text { Past and future bilateral ASAs between } \\
\text { members of the plurilateral and third parties }\end{array}$ & Article 31 & $\begin{array}{l}\text { "1. The States Parties shall not grant rights or give undertakings to third party States where such } \\
\text { rights or undertakings could restrict or affect the rights conferred upon the States Parties under this } \\
\text { Agreement. } \\
\text { 2. The rights conferred upon the States Parties under this Agreement shall not be subject to } \\
\text { individual negotiations or dealings with any third party state or states where such negotiations or } \\
\text { dealings could affect the rights of the other State Party/States Parties. } \\
\text { 3. The arrangements and mechanisms relating to group or multilateral negotiations referred to in } \\
\text { paragraph (2) of this article shall be subject to a regulatory framework in the form of an agreement } \\
\text { which shall enter into force in accordance with the constitutional procedures of each State." }\end{array}$ \\
\hline $\begin{array}{l}\text { Provision to address overlaps with other } \\
\text { plurilateral agreements }\end{array}$ & Article 34 & $\begin{array}{l}\text { "1. Any State Party linked to another State Party or third party State by commitments in the field of } \\
\text { air transport which are in conflict with the provisions of this Agreement shall take the necessary } \\
\text { steps to release itself from such commitments without delay. } \\
\text { 2. Any State Party whose air transport company/companies has/have entered into commitments } \\
\text { which are in conflict with this Agreement shall take the steps necessary to secure release from such } \\
\text { obligations as soon as possible. } \\
\text { 3. The State Party concerned shall inform the General Secretariat to the Commission of the steps } \\
\text { taken in respect of the two eventualities referred to above." } \\
\text { Algeria, Libya, Mauritania, Somalia and Tunisia are also members of Yamoussoukro. } \\
\text { Comoros, Egypt, Djibouti and Sudan are also members of COMESA and of Yamoussoukro }\end{array}$ \\
\hline Accession provisions for third parties & Article 32 & $\begin{array}{l}\text { "The State Party/States Parties shall have the right to exchange the air transport rights stipulated in } \\
\text { this agreement on a basis of reciprocity with any alliance of third party states grouped in a regional } \\
\text { or sub-regional economic integration organization. To this end, the States Parties may call on the } \\
\text { assistance of the Arab Civil Aviation Commission or any other negotiating body which may be } \\
\text { entrusted with this task." }\end{array}$ \\
\hline
\end{tabular}

Source: World Trade Organization (2007). 
Annex Table 3: Turkey's bilateral Air Services Agreements recorded by ICAO, selected indicators (2005)

\begin{tabular}{|c|c|c|c|c|c|}
\hline Party & Date & $\begin{array}{c}\text { Direct } \\
\text { Services }\end{array}$ & $\begin{array}{c}\text { ALI } \\
\text { Standard }\end{array}$ & $\begin{array}{l}\text { Distance } \\
\text { (km) }\end{array}$ & $\begin{array}{c}\text { Traffic Range } \\
\text { (passengers) }\end{array}$ \\
\hline GERMANY & $05 / 07 / 1957$ & Yes & 12 & 2038 & $\begin{array}{l}3500001- \\
4000000\end{array}$ \\
\hline UNITED KINGDOM & $12 / 02 / 1946$ & Yes & 11 & 2502 & $500001-1000000$ \\
\hline FRANCE & $12 / 10 / 1946$ & Yes & 11 & 2256 & $500001-1000000$ \\
\hline NETHERLANDS & $17 / 09 / 1971$ & Yes & 4 & 2210 & $500001-1000000$ \\
\hline UNITED STATES & $02 / 05 / 2000$ & Yes & 28 & 8071 & $1-500000$ \\
\hline ITALY & $25 / 11 / 1949$ & Yes & 15 & 1373 & $1-500000$ \\
\hline SWITZERLAND & $16 / 02 / 1949$ & Yes & 15 & 1837 & $1-500000$ \\
\hline RUSSIAN FEDERATION & 29/08/1967 & Yes & 6 & 1758 & $1-500000$ \\
\hline SPAIN & $15 / 07 / 1975$ & Yes & 13 & 2740 & $1-500000$ \\
\hline AUSTRIA & $31 / 10 / 1967$ & Yes & 10 & 1275 & $1-500000$ \\
\hline GREECE & 22/07/1947 & Yes & 13 & 561 & $1-500000$ \\
\hline BELGIUM & $25 / 10 / 1956$ & Yes & 11 & 2179 & $1-500000$ \\
\hline ISRAEL & 05/02/1951 & Yes & 15 & 1123 & $1-500000$ \\
\hline EGYPT & 12/01/1993 & Yes & 4 & 1240 & $1-500000$ \\
\hline KAZAKHSTAN & 01/05/1992 & Yes & 10 & 3914 & $1-500000$ \\
\hline SWEDEN & $13 / 11 / 1970$ & Yes & 10 & 2173 & $1-500000$ \\
\hline DENMARK & $13 / 11 / 1970$ & Yes & 10 & 2018 & $1-500000$ \\
\hline JAPAN & 08/03/1989 & Yes & 10 & 8959 & $1-500000$ \\
\hline LEBANON & 16/09/1947 & Yes & 11 & 985 & $1-500000$ \\
\hline TUNISIA & $07 / 05 / 1982$ & Yes & 10 & 1684 & $1-500000$ \\
\hline MOLDOVA & 03/06/1995 & Yes & 4 & 664 & $1-500000$ \\
\hline ALBANIA & $26 / 05 / 2003$ & Yes & 13 & 765 & $1-500000$ \\
\hline JORDAN & $07 / 05 / 1948$ & Yes & 11 & 1188 & $1-500000$ \\
\hline SLOVENIA & 03/04/1997 & Yes & 4 & 1291 & $1-500000$ \\
\hline UZBEKISTAN & 23/06/1994 & Yes & 10 & 3344 & $1-500000$ \\
\hline CZECH REPUBLIC & $15 / 04 / 1996$ & Yes & 0 & 1511 & $1-500000$ \\
\hline KYRGYZ REPUBLIC & 14/10/1994 & Yes & 0 & 3737 & $1-500000$ \\
\hline
\end{tabular}




\begin{tabular}{|l|r|l|r|r|l|}
\hline Party & \multicolumn{1}{|c|}{ Date } & $\begin{array}{c}\text { Direct } \\
\text { Services }\end{array}$ & $\begin{array}{c}\text { ALI } \\
\text { Standard }\end{array}$ & $\begin{array}{c}\text { Distance } \\
\text { (km) }\end{array}$ & $\begin{array}{c}\text { Traffic Range } \\
\text { (passengers) }\end{array}$ \\
\hline $\begin{array}{l}\text { SERBIA AND } \\
\text { MONTENEGRO }\end{array}$ & $16 / 04 / 1953$ & No & 11 & 807 & $1-500000$ \\
\hline SYRIAN ARAB REPUBLIC & $06 / 07 / 1949$ & Yes & 11 & 1062 & $1-500000$ \\
\hline PORTUGAL & $13 / 03 / 1992$ & Yes & 4 & 3237 & $1-500000$ \\
\hline NORWAY & $20 / 05 / 1948$ & Yes & 11 & 2447 & $1-500000$ \\
\hline MOROCCO & $24 / 09 / 1985$ & Yes & 6 & 3230 & $1-500000$ \\
\hline HONG KONG, CHINA & $02 / 04 / 1998$ & Yes & 12 & 8026 & $1-500000$ \\
\hline SINGAPORE & $14 / 01 / 1987$ & Yes & 6 & 8660 & $1-500000$ \\
\hline FINLAND & $25 / 03 / 1975$ & Yes & 6 & 2143 & $1-500000$ \\
\hline AFGHANISTAN & $08 / 02 / 1958$ & Yes & 6 & 3582 & $1-500000$ \\
\hline GEORGIA & $30 / 07 / 1992$ & Yes & 6 & 1325 & $1-500000$ \\
\hline FYR MACEDONIA & $09 / 12 / 1994$ & Yes & 10 & 633 & $1-5000000$ \\
\hline LATVIA & $15 / 09 / 1995$ & Yes & 0 & 1805 & $1-5000000$ \\
\hline IRELAND & $24 / 01 / 1980$ & Yes & 6 & 2953 & $1-500000$ \\
\hline PAKISTAN & $02 / 11 / 1955$ & Yes & 12 & 3951 & $1-500000$ \\
\hline BRAZIL & $21 / 09 / 1950$ & No & 15 & 10591 & $1-500000$ \\
\hline CUBA & $29 / 07 / 1993$ & No & 6 & 9985 & $1-500000$ \\
\hline LITHUANIA & $11 / 07 / 1994$ & Yes & 0 & 1543 & $1-500000$ \\
\hline OMAN & $09 / 06 / 1988$ & Yes & 0 & 3372 & $1-500000$ \\
\hline IRAQ & $14 / 05 / 1975$ & No & 10 & 1615 & $<1$ \\
\hline
\end{tabular}

Source: World Trade Organization (2007). 